\title{
Cameroon: Selected Issues
}

This Selected Issues paper for Cameroon was prepared by a staff team of the International Monetary Fund as background documentation for the periodic consultation with the member country. It is based on the information available at the time it was completed on May 30, 2007. The views expressed in this document are those of the staff team and do not necessarily reflect the views of the government of Cameroon or the Executive Board of the IMF.

The policy of publication of staff reports and other documents by the IMF allows for the deletion of market-sensitive information.

To assist the IMF in evaluating the publication policy, reader comments are invited and may be sent by e-mail to publicationpolicy@imf.org.

Copies of this report are available to the public from

International Monetary Fund $\bullet$ Publication Services

700 19th Street, N.W. • Washington, D.C. 20431

Telephone: (202) 6237430 • Telefax: (202) 6237201

E-mail: publications@imf.org • Internet: http://www.imf.org

Price: $\$ 18.00$ a copy

\section{International Monetary Fund Washington, D.C.}





\section{INTERNATIONAL MONETARY FUND}

\section{CAMEROON}

\section{Selected Issues}

Prepared by Iacovos Ioannou, Malangu Kabedi-Mbuyi, Raju Singh, Hans Weisfeld (all AFR), and Romain Veyrune (MCM)

Approved by the African Department

May 30, 2007

Contents

I. Accelerating Growth in Cameroon-Learning from the Experience of Middle-Income

Countries

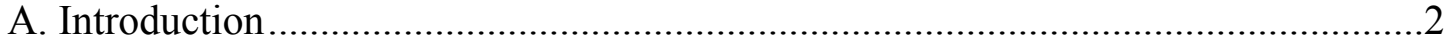

B. Growth Accelerations: A Review of the Literature .............................................

C. Growth Accelerations in Middle-Income Countries: Lessons for Cameroon...........4

II. Cameroon - An Application of the Permanent Income Approach ..................................16

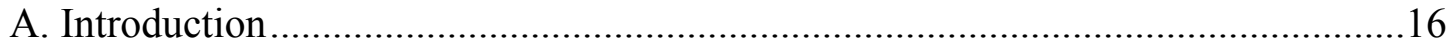

B. Cameroon's Past Experience in Managing Oil Resources....................................16

C. The Permanent Income Approach............................................................... 17

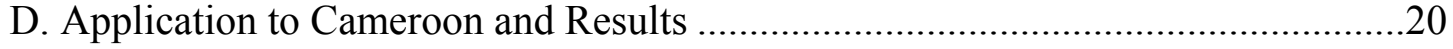

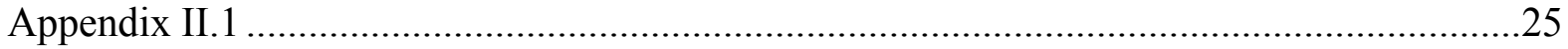

III. Promoting Financial Intermediation: Issues and Reform Prospects .............................27

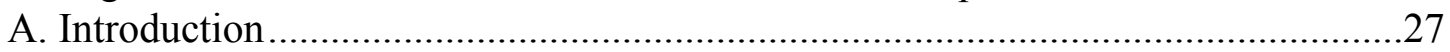

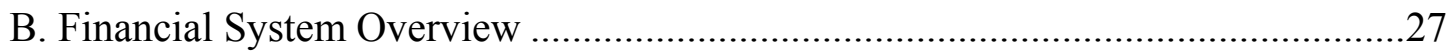

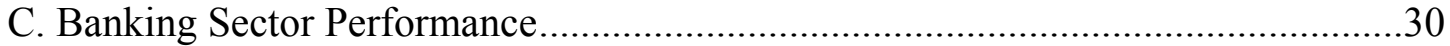

D. Impediments to Financial Intermediation: Key Issues and Possible Reform

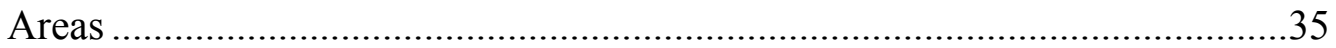

Boxes

II.1. Applying the Permanent Income Approach to Cameroon: Main Assumptions...............20

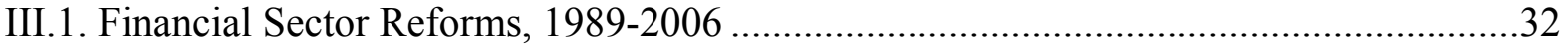

III.2. Findings and Recommendations of the CEMAC Regional FSAP...............................36 


\section{ACCELERATING GROWTH IN CAMEROON-LEARNING FROM THE EXPERIENCE OF Middele-INCOME COUNTRIES ${ }^{1}$}

\section{A. Introduction}

1. Cameroon's economic growth has picked up since 1994, though it remains too low to make a significant dent in poverty. The devaluation of the CFA franc in 1994 and complementary macroeconomic and structural reforms since then have contributed to output growth. Nonetheless, per capita real GDP has not grown as much as in comparator countries. In addition, the record in social development was mixed. The poverty rate declined by about 13 percentage points during 1994-2001.

Education indicators improved, but performance in the health sector was mixed. On the current trajectory, Cameroon is unlikely to meet the MDGs, including the target to halve poverty by 2015 . $^{2}$

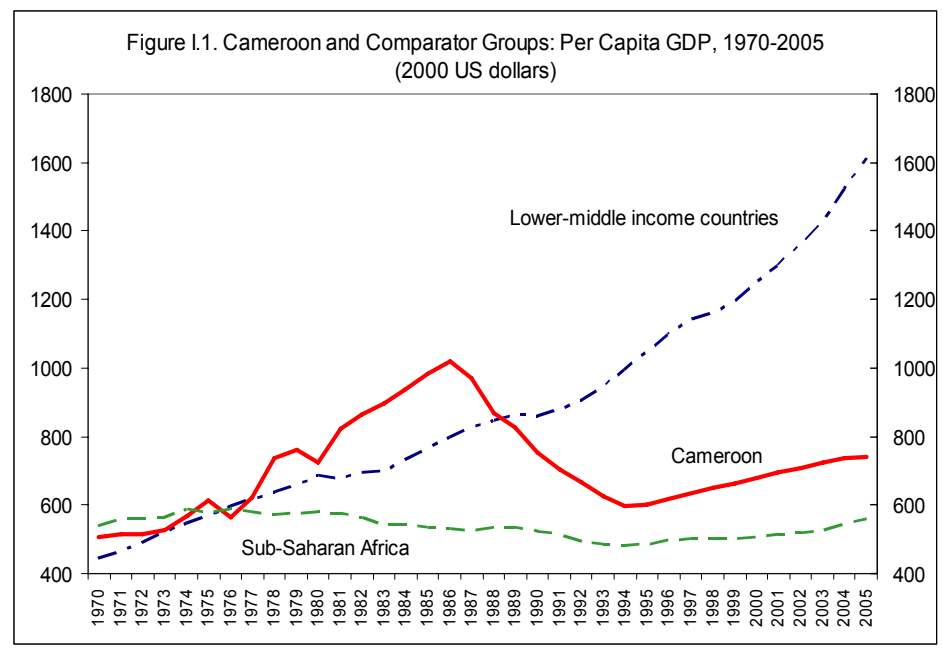

\begin{tabular}{|c|c|c|c|c|}
\hline \multicolumn{5}{|c|}{$\begin{array}{l}\text { Cameroon: Social Indicators, } 1985-2004 \\
\text { (In units indicated; period average) }\end{array}$} \\
\hline & $1985-89$ & $1990-94$ & $1995-99$ & $2000-04$ \\
\hline Adult literacy rate $1 /$ & 53 & 61 & 67 & 71 \\
\hline Primary school enrollment ratio $2 /$ & 102 & 94 & 88 & 107 \\
\hline Secondary school enrollment ratio 3 / & 23 & 28 & 24 & 34 \\
\hline Children immunization ratio 4 / & 44 & 40 & 47 & 64 \\
\hline Infant mortality rate (per 1000 live births) & 147 & 139 & 151 & 150 \\
\hline Life expectancy at birth (years) & 52 & 52 & 49 & 46 \\
\hline \multicolumn{5}{|l|}{ Source: World Bank Social Indicators database. } \\
\hline \multicolumn{5}{|c|}{$\begin{array}{l}\text { 1/ Percent of people ages } 15 \text { and above. } \\
\text { 2/ Percent of the children of primary school age. Includes repeaters. } \\
\text { 3/ Percent of the children of secondary school age. }\end{array}$} \\
\hline
\end{tabular}

2. This chapter identifies impediments to growth acceleration in Cameroon. A twostep approach is followed: first, the characteristics of middle-income countries currently experiencing growth accelerations are examined and, second, the extent to which Cameroon shares these characteristics is assessed. The focus of the analysis is a set of variables the literature has identified as helping to accelerate growth. The main finding is that many of those variables, notably trade openness, adequate infrastructure, and strong institutions, are lacking in Cameroon.

\footnotetext{
${ }^{1}$ Prepared by Iacovos Ioannou.
}

${ }^{2}$ The above assumes a population growth of 2.5 percent per annum. According to the IMF's sub-Saharan Africa Regional Economic Outlook (2005), a real GDP growth of about 7.5 percent would be required for sub-Saharan Africa to meet the Millennium Development Goal of halving income poverty by 2015. 


\section{B. Growth Accelerations: A Review of the Literature}

\section{Recent empirical literature on growth accelerations focuses on turning points in} trend growth. Hausmann, Pritchett, and Rodrik (2004) suggest that the traditional focus of the literature on cross-section or panel econometrics could hide patterns that might explain growth transitions. Looking at jumps in countries' medium-term growth trends might lead to insights into the sources of growth accelerations. ${ }^{3}$

\section{Growth acceleration is defined in terms of the following criteria: ${ }^{4}$}

$>$ Pick up in growth rate. The growth rate after an acceleration episode should exceed the pre-acceleration rate by a given threshold, typically 2 percentage points of real per capita GDP. To gain insights into growth accelerations, the literature focuses on episodes where the acceleration is sustained, comparing backward and forward looking growth rates over a moving window, typically five or seven years.

$>$ Rapid growth. The post-acceleration growth rate in real per capita GDP should exceed a minimum threshold, typically 2 or 3.5 percent.

$>$ Output exceeds the pre-episode peak. Output post-acceleration should be higher to rule out cases of post-crisis recoveries.

5. Growth accelerations are common. Applying the criteria to all countries, developed and developing, Hausmann, Pritchett, and Rodrik (2004) identify more than 80 episodes of rapid accelerations that are sustained for at least eight years during the period 1957-92. Pattillo, Gupta, and Carey (2005) examine growth accelerations in African countries for 1983-1999 and found 34 growth acceleration episodes that were sustained for at least five years.

\section{Growth accelerations are correlated with a number of variables. ${ }^{5}$ Explanatory} variables thought to either trigger or sustain growth accelerations include:

\footnotetext{
${ }^{3}$ The literature on growth acceleration differs from that on the determinants of long-term growth. A country may experience very high growth rates without experiencing growth acceleration, and it may experience growth acceleration without necessarily experiencing a very high growth rate.

${ }^{4}$ See for example Hausmann, Pritchett, and Rodrik (2004) and Pattillo Gupta, and Carey (2005).

${ }^{5}$ The predictive power of these models is limited. Explanatory variables account for only a small part of the probability of growth acceleration. Growth can accelerate when growth correlates are not present; conversely, growth accelerations do not always occur when the correlates are present. This conclusion is drawn both by Hausmann, Pritchett, and Rodrik (2004) and Pattillo, Gupta, and Carey (2005).
} 
Fiscal Policy. Pattillo, Gupta, and Carey (2005) note that growth accelerations do not come at the expense of fiscal sustainability. The budget deficit is either insignificantly different or better during rather than before an acceleration episode.

$>$ Trade openness. Hausmann, Pritchett, and Rodrik (2004) and Pattillo, Gupta, and Carey (2005) conclude that trade-related factors have the strongest and most robust association with growth acceleration. The literature tries to capture the effect of trade by trade partner growth, competitiveness indicators, and the terms of trade.

Investment and productivity. Hausmann, Pritchett, and Rodrik (2004) find that growth accelerations coincide with an increase in the investment ratio, a result confirmed by Pattillo, Gupta, and Carey (2005). Pattillo, Gupta, and Carey (2005) also find that productivity growth has a positive impact on growth acceleration.

$>$ Economic reforms. The important role of economic reforms in triggering and sustaining growth accelerations in African countries is confirmed by Patillo, Gupta, and Carey (2005). Hausmann, Pritchett, and Rodrik (2005) find a strong association between financial liberalization and growth acceleration, especially in developing countries. $^{6}$

D Debt burden. Pattillo, Gupta, and Carey (2005) find that a low debt burden is positively associated with growth acceleration. In particular, debt concessionality is found to be an important factor explaining the lower debt service burden associated with recent growth acceleration episodes. The issue of concessionality is especially important because countries where growth is accelerating in general exhibit a rising debt-to-GDP ratio.

$>$ Governance and the quality of institutions. Pattillo, Gupta, and Carey (2005) show that the quality of institutions is correlated with growth accelerations. Growth is more likely to accelerate in countries that score high on the soundness of their institutions than in countries with weak institutions. This effect may also be captured by the productivity variable, which as a residual variable may pick up improvements in institutional quality in addition to other productivity gains.

\section{Growth Accelerations in Middle-Income Countries: Lessons for Cameroon}

7. Cameroon's main comparator is the group of middle-income countries. The two studies cited relied on a sample that was either too broad (including developed countries) or

\footnotetext{
${ }^{6}$ Hausmann, Pritchett, and Rodrik (2004) found fundamental economic reforms to be correlated with "sustained" growth accelerations. Sustained accelerations are those where the jump in the growth rate of per capita GDP is sustained beyond the time period defined as a growth acceleration (i.e., five to eight years).
} 
too narrow (African countries only). Too broad a sample runs the risk that the conclusions may not be relevant for Cameroon. Focusing only on African countries may mask positive experiences of other countries that may be relevant for Cameroon. Balancing these considerations, and taking into account Cameroon's current status as a middle-income country, this chapter examines growth accelerations in middle-income countries. The group was selected using the 2005 gross national income (GNI) per capita, calculated using the Atlas method. ${ }^{7}$ The sample consists of 98 countries, of which 58 are lower-middle-income countries (per capita GNI between $\$ 876$ and $\$ 3,465$ ) and 40 upper-middle-income (per capita GNI between $\$ 3,466$ and $\$ 10,725$ ). Nine countries (mostly small island states) were dropped from the sample due to lack of data. The 89 countries in the sample are listed in Table I.1.

\section{Stylized facts about growth acceleration in middle-income countries}

\section{Growth acceleration episodes in middle-income countries are identified based on} the criteria specified earlier. Though in the literature assumptions used to identify growth acceleration episodes vary somewhat, this study identifies such episodes by comparing backward and forward-looking growth rates in per capita GDP over a five-year moving window. ${ }^{8}$ The growth rate over a given five year period is calculated by running the regression of the log of per capita GDP on a constant trend:

$$
\ln \left(\mathrm{y}_{\mathrm{t}+\mathrm{i}}\right)=\mathrm{a}+\mathrm{g}_{\mathrm{t}, \mathrm{t}+\mathrm{n}} * \mathrm{t}, \quad \mathrm{i}=0, \ldots \mathrm{n}=5
$$

where: $\mathrm{y}_{\mathrm{t}+\mathrm{i}}=$ real per capita GDP at time $\mathrm{t}$ over the period $\mathrm{t}$ to $\mathrm{t}+\mathrm{n}$;

$$
\mathrm{g}_{\mathrm{t}, \mathrm{t}+\mathrm{n}}=\text { the least squares growth rate over a horizon } \mathrm{n}
$$

Specifically, a growth acceleration episode requires (i) a jump in the forward looking rate by at least 2 percentage points relative to the backward-looking rate; (ii) a post-jump per capita GDP growth rate of at least 2 percent, ${ }^{9}$ and (iii) a post-acceleration level of GDP that exceeds the pre-acceleration level. The data cover 1985-2006, making it possible to identify growth acceleration episodes between 1990 and 2001. ${ }^{10}$

\footnotetext{
${ }^{7}$ This classification remains in effect until July 1, 2007.

${ }^{8}$ Hausmann, Pritchett, and Rodrik (2004) use an eight-year window. Reducing the size of the window to five years makes it possible to identify acceleration episodes as recent as 2001 .

${ }^{9}$ A high post jump rate would make it possible to capture countries growing strongly after the acceleration episode, rather than countries experiencing acceleration from a low growth rate.

${ }^{10}$ In contrast, Hausmann, Pritchett, and Rodrik (2004) use data that enable them to identify growth acceleration episodes during 1957-92; Pattillo Gupta, and Carey (2005) identify growth acceleration episodes in 1983-1999.
} 
9. Growth accelerations in middle-income countries are quite frequent. Consistent with the literature, the sample reveals a surprisingly large number (78) of growth acceleration episodes (Table 2). Nine countries had more than one acceleration episodes; 20 (including Cameroon) had none. Given the duration of a typical episode and the growth differential post and pre-acceleration, a typical growth acceleration episode implies a gain in output of more than 40 percent by the end of the acceleration. ${ }^{11}$ In line with the approach taken by Hausmann, Pritchett, and Rodrik (2004), the unconditional probability of growth acceleration is 15 percent. ${ }^{12}$ This means that a typical country would have about a 15 percent probability of experiencing growth acceleration at some point during the sample period. Most accelerations (27) took place in Europe and Central Asia, followed by Latin America and the Caribbean (23), the Middle East and North Africa (10), East Asian and the Pacific (9), subSaharan Africa (7) and South Asia (2).

\begin{tabular}{|l|l|}
\hline \multicolumn{2}{|c|}{ Middle-income Countries: Growth Acceleration Episodes } \\
\hline Frequency & 78 episodes \\
\hline Number of countries & 69 countries \\
\hline Average duration & 6.7 years \\
\hline Average growth rate post acceleration & 4.8 percent \\
\hline Average growth rate pre-acceleration & -1.3 \\
\hline
\end{tabular}

\section{Cameroon is among the few countries that has not experienced growth}

acceleration. For 1991-97 it did benefit from a pick up in growth that exceeded the 2 percent threshold, but the post acceleration growth rate was below the 2 percent threshold. ${ }^{13}$ As a result, it did not meet the criteria for growth acceleration.

\footnotetext{
${ }^{11}$ Hausmann, Pritchett, and Rodrik (2004) also report output gains of almost 40 percent relative to the preacceleration period.

${ }^{12}$ This probability is estimated by dividing the number of episodes by the number of years in which growth accelerates.

${ }^{13}$ In effect, the pick up in Cameroon's growth rate was the result of either less rapid decline in output or modestly higher output, which when compared to the previous negative growth rates, resulted in a jump in the growth rate.
} 


\section{Impediments to growth acceleration in Cameroon ${ }^{14}$}

\section{Cameroon's fiscal balance compares favorably with that of other countries} experiencing growth acceleration. With an average fiscal surplus of 1.4 percent for 200005 (the period coinciding with the latest acceleration episode), the fiscal balance does not seem to represent a drag on growth acceleration. In fact, there may be some additional fiscal space that could be used to spur growth, so long as fiscal sustainability is maintained. ${ }^{15}$

\section{Other aspects of fiscal policy, however, show potential weaknesses. Countries} experiencing growth acceleration have on average a ratio of tax revenue-to-GDP of about 25 percent; Cameroon's is 17 percent. This ratio is not affected by the level of development of a country; lower- and upper-middle-income countries have similar tax ratios. Middleincome countries with growth acceleration also have significantly higher expenditure-toGDP ratios than Cameroon. It would thus appear that Cameroon should step up its efforts to mobilize nonoil tax revenues so that it can finance additional expenditure. Another lesson drawn from the experience of middle-income countries with growth acceleration is that Cameroon should reorient expenditure away from consumption. While total expenditure of middle-income countries experiencing growth acceleration is on average higher than that of Cameroon by more than 10 percentage points of GDP, real public consumption expenditure in such countries is higher only by 1 percentage point. Cameroon's capital to total spending ratio therefore seems to be too low.

\footnotetext{
${ }^{14}$ The analysis below only indicates possible obstacles to growth acceleration in Cameroon. It does not establish any causal relationship between the variables considered in this chapter and growth acceleration. The source of the data is the World Bank's Development Indicators. Since data for the associated variables were not available for 2006, all country data are based on 2000-05.

${ }^{15}$ Although there is evidence that middle-income countries experiencing growth acceleration have modestly higher fiscal deficits, concluding that Cameroon should also run higher deficits should be based on a careful assessment of fiscal sustainability rather than on a mechanistic adoption of a fiscal deficit target based on the experience of other countries. In essence, the appropriate fiscal balance conducive to growth acceleration would be one that is consistent with fiscal sustainability.
} 
Figure I.2. Fiscal Performance: Cameroon Versus Middle- Income Countries (MICs) with Growth Acceleration ${ }^{1}$ (Percent of GDP)

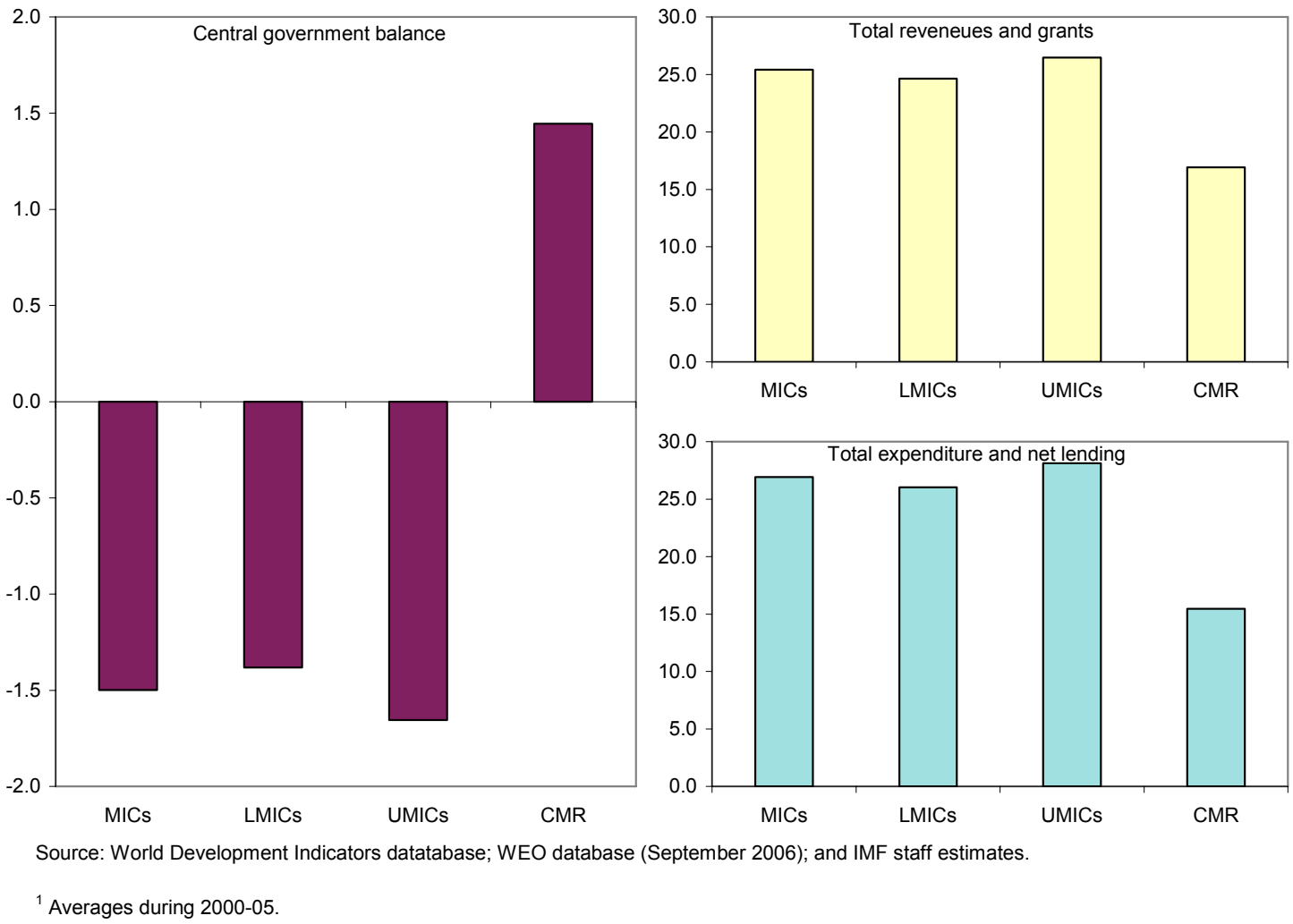

13. Cameroon's trade is limited compared to that of other countries experiencing growth acceleration. Trade in countries experiencing growth acceleration is more than double Cameroon's, with both exports and imports higher. The increased export activity is not related to the oil boom. In fact, the average value of fuel exports in this group of countries is about one-third of the corresponding value in Cameroon. Data on the volume of nonoil exports also show that countries experiencing growth acceleration export on average 20 times more than Cameroon.

14. Cameroon has the lowest competitiveness ranking of all countries in the sample. Data from the Global Competitiveness Index indicate that countries experiencing growth acceleration had a significantly lower percentile ranking than Cameroon. Weak competitiveness could therefore account for Cameroon's limited trade activity. In addition to competitiveness, countries experiencing growth acceleration benefited from favorable terms of trade. A positive exogenous shock, however, does not seem to explain trade buoyancy. The average terms of trade shock among middle-income countries experiencing growth acceleration was 3 percent — not enough to account for the large trade openness gap between countries with growth acceleration and Cameroon. 
Figure I.3. Trade Performance: Cameroon Versus Middle-Income Countries (MICs) with Growth Acceleration ${ }^{1}$
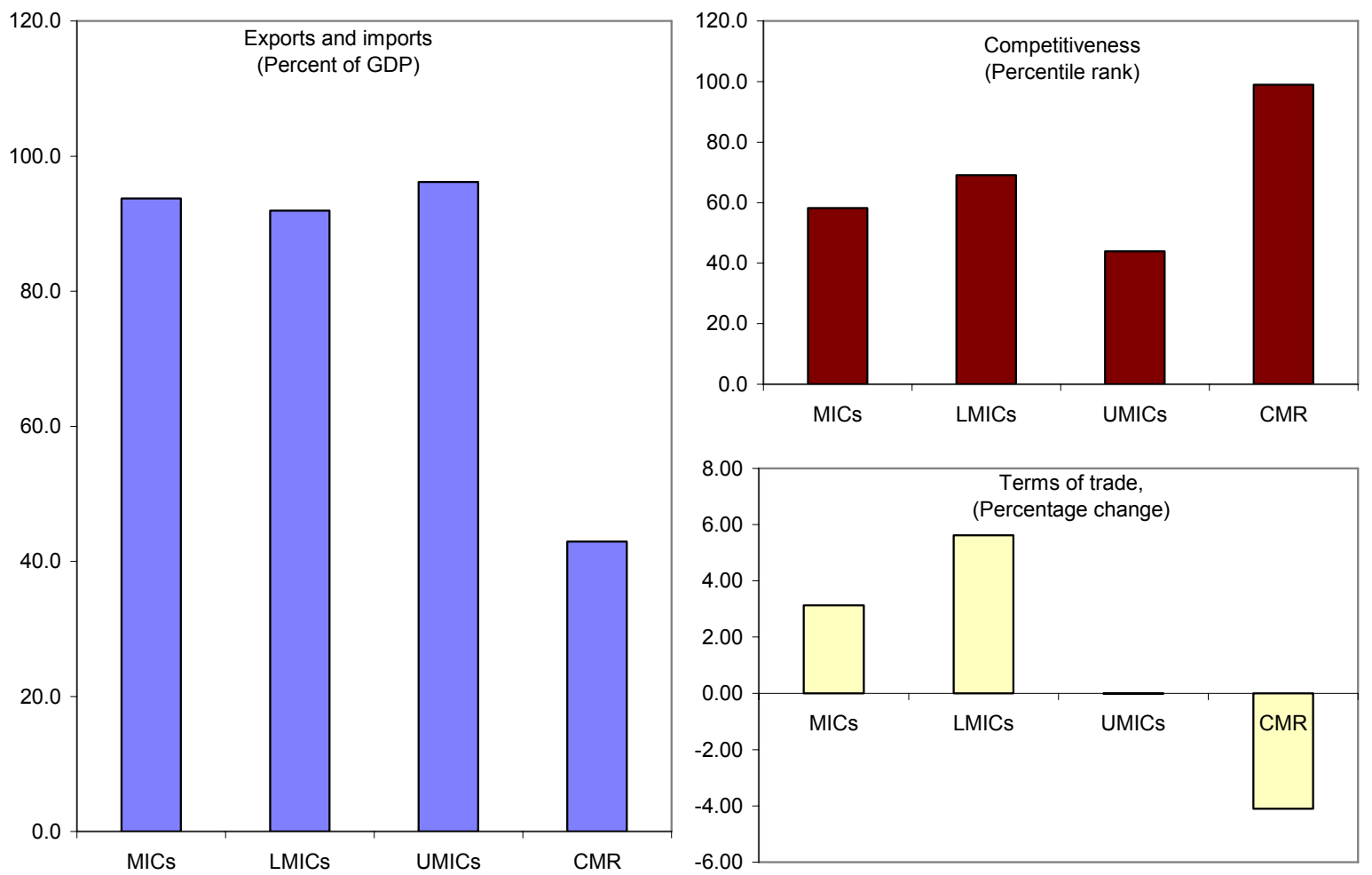

Source: World Development Indicators datatabase; WEO database (September 2006); and IMF staff estimates.

${ }^{1}$ Averages during 2000-05.

15. Infrastructure development is an area where Cameroon lags behind all countries in the sample. Several indicators were examined, including agricultural machinery (tractors) per arable land, the number of personal computers per 1,000 people, and number of mobile and landline telephones per 1,000 people. ${ }^{16}$ Differences in infrastructure development can be partly accounted for by differences in foreign investment flows. Countries experiencing growth acceleration had net investment flows about 5 times larger than Cameroon's.

16. Middle-income countries experiencing growth acceleration may have been more committed to reform than Cameroon. Financial intermediation (measured as the ratio of bank credit to GDP), a proxy for financial sector reform, was considerably larger in middleincome countries experiencing growth acceleration than in Cameroon. Among the countries sampled, only three did worse in this area. Cameroon may therefore have to reform its financial system to facilitate infrastructure improvements.

\footnotetext{
${ }^{16}$ Except for mobile phone lines, the gap between Cameroon and middle-income countries experiencing growth acceleration is large.
} 
Figure 1.4. Infrastructure Development: Cameroon Versus Middle-Income Countries (MICs) with Growth Acceleration ${ }^{1}$ (Percent of GDP)

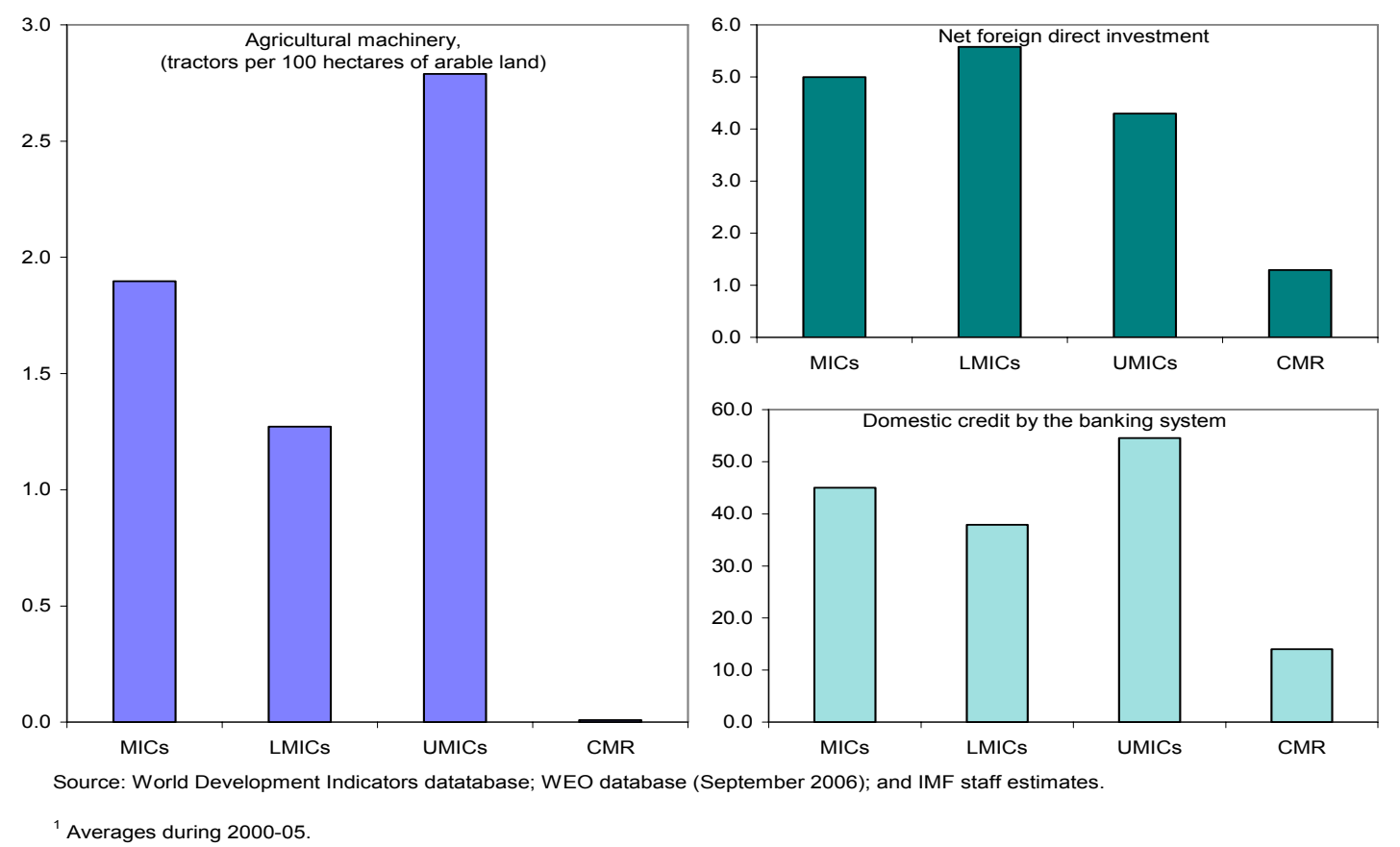

17. Cameroon's public debt and foreign aid compare favorably to that of other middle-income countries experiencing growth acceleration. Although countries experiencing growth acceleration had moderate levels of public debt, Cameroon's is considerably lower, especially after the HIPC completion point. Nevertheless, prudent fiscal and debt management policies should be maintained to ensure that public debt does not rise rapidly. A key attribute of countries experiencing growth acceleration is that they have relatively low debt service. This would suggest that Cameroon should continue to rely on concessional financing over the medium term. Countries experiencing growth acceleration had about one-third as much foreign aid as Cameroon. Most of the countries experiencing the fastest growth acceleration had negligible amounts of foreign aid.

18. The quality of institutions in Cameroon is weak compared with that in middleincome countries experiencing growth acceleration. Cameroon ranks very low on most dimensions of governance, especially in the areas of control of corruption and the rule of law. Improving the business environment should also be a priority: business indicators in Cameroon, especially contract enforcement, lag behind those in comparator countries with growth acceleration. ${ }^{17}$

\footnotetext{
${ }^{17}$ The widespread misconception that companies in Cameroon are overtaxed is not supported by the data. While the tax system is indeed complex and in need of simplification to reduce the cost of compliance, the amount of taxes as a percent of gross profits is similar to that of other middle-income countries experiencing growth acceleration.
} 
Figure 1.5. Debt Service and Foreign Aid: Cameroon Versus Middle-Income Countries (MICs) with Growth Acceleration (Percent of GNI)
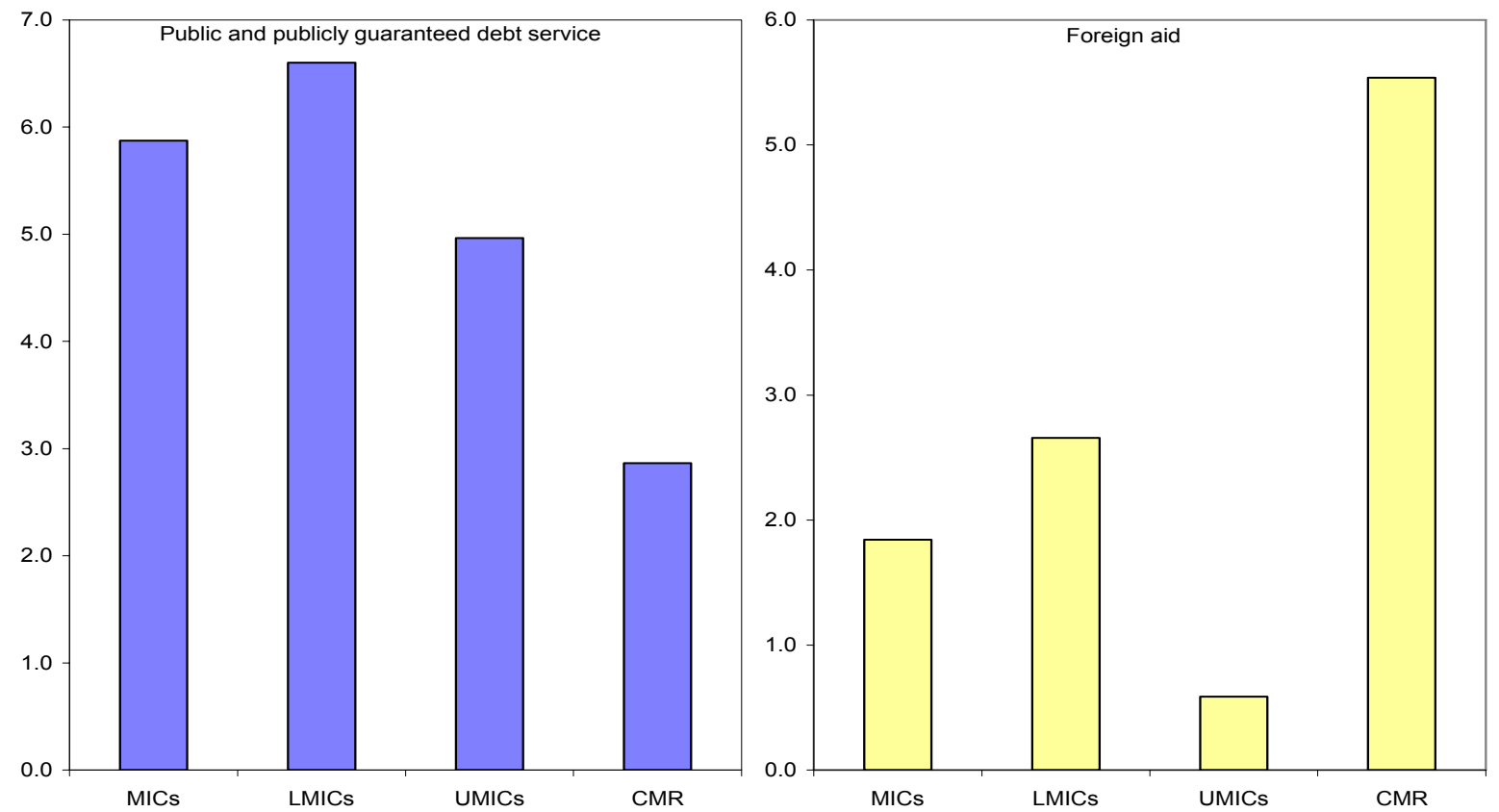

Source: World Development Indicators database; Cameroonian authorities: and IMF staff estimates

${ }^{1}$ Averages during 2000-05.

Figure I.6. Governance and Institutions: Cameroon Versus Middle-Income Countries (MICs) with Growth Acceleration
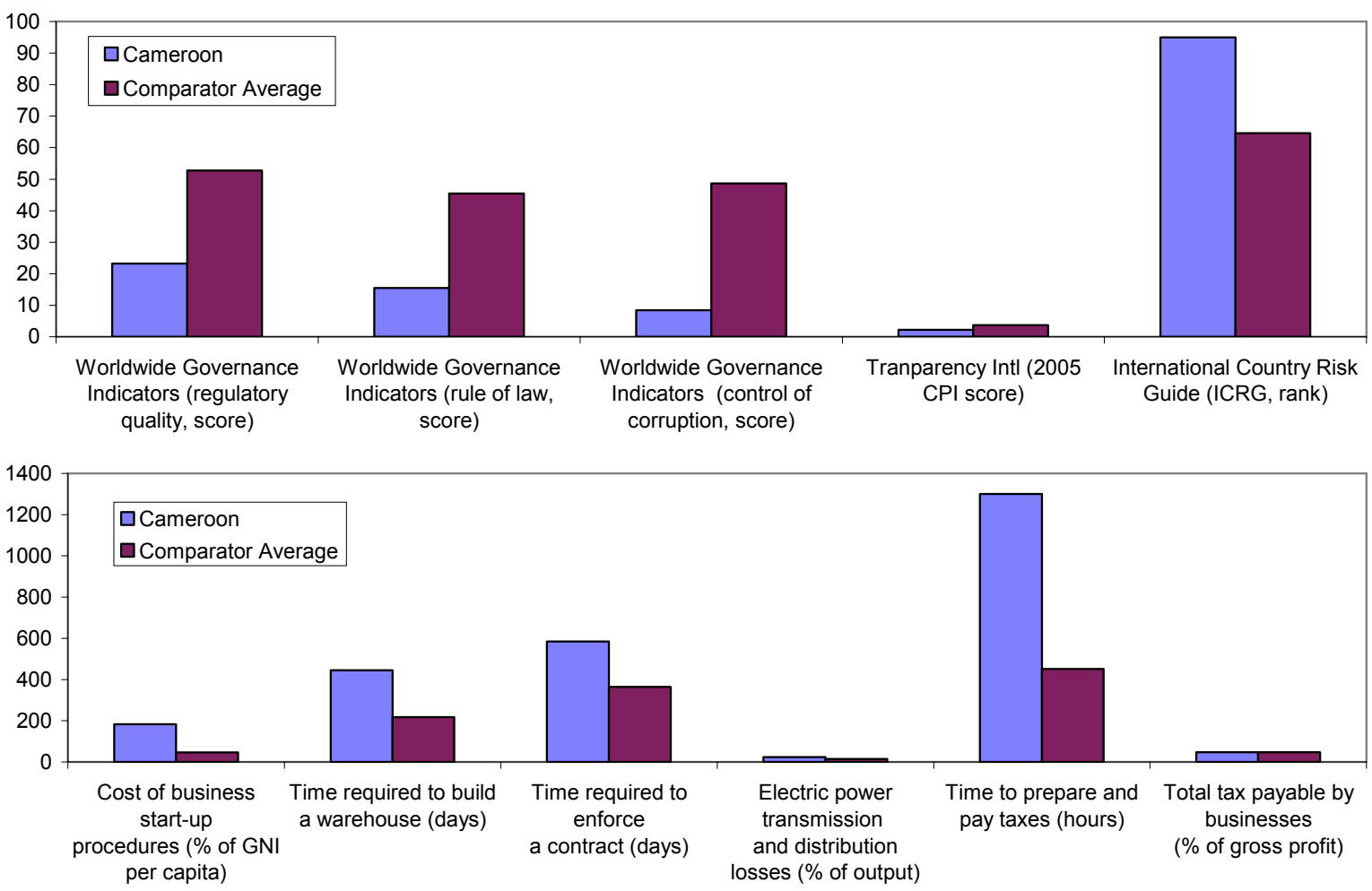

Source: World Development Indicators database; Cameroonian authorities; and IMF staff estimates.

${ }^{1}$ Averages during 2000-05 
Table I.1. Sample of Middle-income Countries

\begin{tabular}{|c|c|c|c|}
\hline Country & & Lebanon & UMIC \\
\hline Albania & LMIC & Lesotho & LMIC \\
\hline Algeria & LMIC & Libya & UMIC \\
\hline Angola & LMIC & Lithuania & UMIC \\
\hline Argentina & UMIC & Macedonia, FYR & LMIC \\
\hline Armenia & LMIC & Malaysia & UMIC \\
\hline Azerbaijan, Rep. of & LMIC & Maldives & LMIC \\
\hline Barbados & UMIC & Mauritius & UMIC \\
\hline Belarus & LMIC & Mexico & UMIC \\
\hline Belize & UMIC & Moldova & LMIC \\
\hline Bolivia & LMIC & Morocco & LMIC \\
\hline Bosnia \& Herzegovina & LMIC & Namibia & LMIC \\
\hline Botswana & UMIC & Nicaragua & LMIC \\
\hline Brazil & LMIC & Oman & UMIC \\
\hline Bulgaria & LMIC & Panama & UMIC \\
\hline Cameroon & LMIC & Paraguay & LMIC \\
\hline Cape Verde & LMIC & Peru & LMIC \\
\hline Chile & UMIC & Philippines & LMIC \\
\hline China,P.R.: Mainland & LMIC & Poland & UMIC \\
\hline Colombia & LMIC & Romania & UMIC \\
\hline Congo, Republic of & LMIC & Russia & UMIC \\
\hline Costa Rica & UMIC & Samoa & LMIC \\
\hline Croatia & UMIC & Serbia \& Montenegro & LMIC \\
\hline Czech Republic & UMIC & Seychelles & UMIC \\
\hline Djibouti & LMIC & Slovak Republic & UMIC \\
\hline Dominica & UMIC & South Africa & UMIC \\
\hline Dominican Republic & LMIC & Sri Lanka & LMIC \\
\hline Ecuador & LMIC & St. Kitts and Nevis & UMIC \\
\hline Egypt & LMIC & St. Lucia & UMIC \\
\hline El Salvador & LMIC & St. Vincent \& Grens. & UMIC \\
\hline Equatorial Guinea & UMIC & Suriname & LMIC \\
\hline Estonia & UMIC & Swaziland & LMIC \\
\hline Fiji & LMIC & Syrian Arab Republic & LMIC \\
\hline Gabon & UMIC & Thailand & LMIC \\
\hline Georgia & LMIC & Tonga & LMIC \\
\hline Grenada & UMIC & Trinidad and Tobago & UMIC \\
\hline Guatemala & LMIC & Tunisia & LMIC \\
\hline Guyana & LMIC & Turkey & UMIC \\
\hline Honduras & LMIC & Turkmenistan & LMIC \\
\hline Hungary & UMIC & Ukraine & LMIC \\
\hline Indonesia & LMIC & Uruguay & UMIC \\
\hline Iran, I.R. of & LMIC & Vanuatu & LMIC \\
\hline Jamaica & LMIC & Venezuela, Rep. Bol. & UMIC \\
\hline Jordan & LMIC & & \\
\hline Kazakhstan & LMIC & & \\
\hline Kiribati & LMIC & & \\
\hline Latvia & UMIC & & \\
\hline
\end{tabular}


Table I.2. Growth Acceleration Episodes in Middle Income Countries, 1990-2001

\begin{tabular}{|c|c|c|c|c|c|}
\hline Country & Starting Year & Duration in Years 1 & 1 Growth before Onset & Growth After Onset & Growth Differential \\
\hline Albania & 1994 & & -6.5 & 4.4 & 10.9 \\
\hline Algeria & 2001 & & 1.4 & 3.7 & 2.3 \\
\hline Angola & 2000 & & 2.0 & 6.6 & 4.6 \\
\hline Argentina & 1990 & & -2.1 & 5.3 & 7.4 \\
\hline Argentina & 2001 & & -0.1 & 4.6 & 4.6 \\
\hline Armenia & 1996 & 10 & -13.1 & 7.9 & 21.0 \\
\hline Azerbaijan & 1997 & & -12.2 & 6.5 & 18.7 \\
\hline Barbados & 1994 & & -3.1 & 3.3 & 6.4 \\
\hline Belarus & 1996 & & -8.7 & 6.6 & 15.4 \\
\hline Belize & 1996 & & 1.4 & 4.1 & 2.7 \\
\hline Bosnia and Herzegovina & 1991 & & -0.6 & 14.1 & 14.6 \\
\hline Botswana & 1994 & & 1.5 & 5.9 & 4.4 \\
\hline Brazil & 1991 & & -1.3 & 2.2 & 3.6 \\
\hline Bulgaria & 1997 & & -4.8 & 4.7 & 9.5 \\
\hline Cape Verde & 1991 & & 1.0 & 3.9 & 2.9 \\
\hline Chile & 2001 & & 1.6 & 3.6 & 2.0 \\
\hline China, PR & 1990 & & 6.4 & 10.8 & 4.4 \\
\hline Colombia & 2001 & & -1.5 & 2.5 & 4.0 \\
\hline Croatia & 1995 & & -4.6 & 3.3 & 8.0 \\
\hline Czech Republic & 2000 & & 1.1 & 3.6 & 2.4 \\
\hline Dominican Republic & 1991 & 10 & -0.3 & 3.5 & 3.8 \\
\hline Ecuador & 1999 & & -0.7 & 3.6 & 4.3 \\
\hline Egypt & 1993 & & 0.0 & 3.1 & 3.1 \\
\hline El Salvador & 1990 & & 0.6 & 4.1 & 3.6 \\
\hline Equatorial Guinea & 1990 & 11 & -4.9 & 7.1 & 12.0 \\
\hline Estonia & 1995 & & -6.2 & 6.4 & 12.6 \\
\hline Estonia & 2001 & & 6.0 & 8.2 & 2.2 \\
\hline Georgia & 1996 & & -14.0 & 5.0 & 19.1 \\
\hline Georgia & 2001 & & 5.0 & 7.8 & 2.8 \\
\hline Grenada & 1995 & & 1.3 & 3.5 & 2.2 \\
\hline Guyana & 1990 & & -2.2 & 6.7 & 9.0 \\
\hline Hungary & 1994 & & -3.8 & 3.4 & 7.2 \\
\hline Indonesia & 1999 & & -0.6 & 3.5 & 4.1 \\
\hline Iran & 1995 & & -0.7 & 3.6 & 4.2 \\
\hline Jordan & 2000 & & 0.6 & 3.3 & 2.7 \\
\hline Kazakhstan & 1996 & 10 & -6.1 & 5.2 & 11.3 \\
\hline Kiribati & 1991 & 11 & -0.7 & 2.4 & 3.1 \\
\hline Latvia & 1996 & & -5.6 & 6.9 & 12.5 \\
\hline Latvia & 2001 & & 6.9 & 8.9 & 2.0 \\
\hline Lebanon & 1993 & & -2.5 & 2.8 & 5.3 \\
\hline Lebanon & 2000 & & 0.1 & 2.7 & 2.6 \\
\hline Libya & 1999 & & -0.1 & 2.7 & 2.8 \\
\hline Lithuania & 1996 & & -8.2 & 4.7 & 12.9 \\
\hline Lithuania & 2000 & & 5.3 & 8.0 & 2.7 \\
\hline Malaysia & 2001 & & 0.2 & 3.7 & 3.4 \\
\hline Maldives & 1992 & & 1.1 & 4.8 & 3.7 \\
\hline Mexico & 1995 & & 0.2 & 3.8 & 3.6 \\
\hline Moldova & 1998 & & -5.2 & 4.3 & 9.5 \\
\hline Morocco & 2001 & & 1.0 & 3.1 & 2.0 \\
\hline Namibia & 1999 & & 0.6 & 2.7 & 2.1 \\
\hline Nicaragua & 1994 & & -2.5 & 2.6 & 5.1 \\
\hline Panama & 1990 & & -4.0 & 3.5 & 7.5 \\
\hline Peru & 1993 & & -4.1 & 3.9 & 8.0 \\
\hline Peru & 2000 & & 0.6 & 2.7 & 2.1 \\
\hline Philippines & 1993 & & -0.5 & 2.1 & 2.7 \\
\hline Philippines & 2001 & & 0.9 & 3.1 & 2.3 \\
\hline Poland & 1991 & & -1.1 & 4.7 & 5.8 \\
\hline Romania & 1998 & & 1.6 & 4.0 & 2.5 \\
\hline Russia & 1997 & & -6.0 & 5.3 & 11.3 \\
\hline Samoa & 1991 & & 0.1 & 4.5 & 4.4 \\
\hline Seychelles & 1994 & & 3.3 & 5.4 & 2.1 \\
\hline Slovak Republic & 1995 & & -3.3 & 3.4 & 6.7 \\
\hline Slovak Republic & 2001 & & 2.8 & 5.1 & 2.3 \\
\hline South Africa & 2001 & & 0.9 & 3.0 & 2.0 \\
\hline Sri Lanka & 1990 & & 2.0 & 4.1 & 2.1 \\
\hline St. Kitts and Nevis & 1994 & & 2.4 & 4.8 & 2.4 \\
\hline St. Lucia & 2001 & & -0.2 & 2.8 & 3.0 \\
\hline St Vincent and Grens & 1994 & & 3.0 & 5.1 & 2.1 \\
\hline Suriname & 2000 & & 0.3 & 3.3 & 2.9 \\
\hline Syrian Arab Rep. & 1990 & & -0.7 & 4.9 & 5.5 \\
\hline Thailand & 1999 & & -0.6 & 3.9 & 4.5 \\
\hline Tonga & 1998 & & 0.7 & 2.9 & 2.2 \\
\hline Trinidad and Tobago & 1992 & 10 & -1.2 & 3.8 & 5.0 \\
\hline Tunisia & 1995 & & 2.0 & 4.1 & 2.1 \\
\hline Turkey & 2001 & & -0.9 & 5.4 & 6.2 \\
\hline Turkmenistan & 1997 & & -14.5 & 14.2 & 28.7 \\
\hline Ukraine & 1998 & & -9.6 & 7.1 & 16.7 \\
\hline Uruguay & 2001 & & -0.6 & 4.8 & 5.4 \\
\hline
\end{tabular}

Source: IMF staff estimates.

${ }^{1}$ The duration of growth accelerations ending in 2006 can not be ascertained as it requires data beyond 2006 (currently not available). 


\section{References}

Barro, Robert J., 1991, "Economic Growth in a Cross Section of Countries," Quarterly Journal of Economics, Vol. 106 (May), pp. 407- 443

Bekaert Geert, Cambell Harvery, and Christian Lundblad, 2001, "Does Financial Liberalization Spur Growth?” NBER Working Paper No. 8245 (Cambridge, Massachusetts: MIT).

Collier, Paul and Jan Willem Gunning, 1999, "Explaining African Growth Performance," Journal of Economic Literature, Vol. 37 (March), pp. 64-111.

Hausmann, Ricardo, Lant Pritchett, and Dani Rodrik, 2004, “Growth Accelerations,"NBER Working Paper No. 10566 (Cambridge, Massachusetts: MIT).

Hausmann, Ricardo, Dani Rodrik, and Andrés Velasco, 2005, "Growth Diagnostics," Harvard University (Cambridge, Massachusetts).

ICRG, available at http://www.icrgonline.com

International Monetary Fund, 2005, “Can PRGF Policy Levers Improve Institutions and Lead to a Sustained Growth?”, (Washington: International Monetary Fund).

International Monetary Fund, 2005, Regional Economic Outlook: Sub-Saharan Africa, IMF Publications (Washington:International Monetary Fund).

Marshall, Monty G. and Keith Jaggers, 2002. Polity IV Dataset, available at htpp://cidcm.umd.edu/inscr/polity.

Pattillo, Catherine, Sanjeev, Gupta and Kevin Carey, 2005, "Sustaining Growth Accelerations and Pro-Poor Growth in Africa," IMF Working Paper 05/195 (Washington: International Monetary Fund).

Rodrik, Dani, 1999, "Where did all the Growth Go? External Shocks, Social Conflict, and Growth Collapses," Journal of Economic Growth, Vol. 4 (December), pp. 385-412.

Sachs, Jeffrey and Andrew Warner, 1995, "Economic Convergence and Economic Policies," Brookings Papers on Economic Activity, ed. by William Brainard and George Perry.

Sachs, Jeffrey and Andrew Warner, 1997, "Sources of Slow Growth in African Economies," Journal of African Economies, Vol. 6 (October), pp. 335-76.

Subramanian, Arvind and Devesh Roy, 2001, "Who Can Explain The Mauritian Miracle: Meade, Romer, Sachs or Rodrik?” IMF Working Paper 01/116 (Washington: International Monetary Fund). 
Tahari, Amor, Dhaneshwar Ghura, Bernardin Akitoby, and Emmanuel Brou Aka, 2004, "Sources of Growth in Sub-Saharan Africa," IMF Working Paper 04/176 (Washington: International Monetary Fund).

Temple, Jonathan, 1999, “The New Growth Evidence," Journal of Economic Literature, Vol. 37 (March), pp. 112-156.

Wacziarg, Romain, and Karen Horn Welch, 2003, "Trade Liberalization and Growth: New Evidence,” NBER Working Paper No. 10152 (Cambridge, Massachusetts: MIT).

World Bank, Doing Business Database, available at http://rru.worldbank.org/DoingBusiness/

World Bank, Worldwide Governance Indicators, available at http://info.worldbank.org/governance/

World Economic Forum, Global Competitiveness Index, available at http://www.weforum.org. 


\section{CAMERoon-An Application Of The Permanent InCome ApProach ${ }^{1}$}

\section{A. Introduction}

1. Resource rich countries face a unique set of fiscal challenges. These include managing the volatility of commodity revenue and planning for resource depletion, in particular through efforts to strike the right balance between spending and saving for future generations. $^{2}$

\section{Cameroon's economic history illustrates the pitfalls of implementing a} procyclical fiscal policy. As oil production increased rapidly in the late 1970s and early 1980s, Cameroon's spending expanded to levels that were difficult to scale back once oil revenue started to decline, resulting in mounting public debt. In order to avoid such setbacks, it is important to develop a medium-term fiscal strategy that keeps debt sustainable while allowing for scaled-up spending to meet pressing social needs.

\section{This paper presents a possible fiscal strategy for Cameroon based on the} permanent income approach. According to this approach, Cameroon could permanently sustain primary public spending of 15.4 percent of nonoil GDP a year from 2007 on as long as efforts to mobilize additional nonoil revenue are borne out.

\section{B. Cameroon's Past Experience in Managing Oil Resources}

4. Cameroon's oil output is declining. Cameroon's oil production, which grew rapidly after its start in 1978, peaked at 180,000 barrels per day in 1985. Since then, production has trended downward, reaching 87,000 barrels per day in 2006 (Figure II.1), making Cameroon one of sub-Saharan Africa's smallest oil producers. ${ }^{3}$ In 2006 its oil sector accounted for about 10 percent of GDP, 35 percent of fiscal revenue, and 55 percent of exports. Cameroon has 540 million barrels of proven oil reserves and an additional 960 million barrels of probable oil reserves, as well as probable natural gas reserves equivalent to 700 million barrels of oil (Figure II.2). Natural gas production is expected to start in 2008.

\footnotetext{
${ }^{1}$ Prepared by Hans Weisfeld.

2 The literature describing and analyzing the "natural resource curse" initiated by Sachs and Warner (1995) has grown steadily. See, for example, Manzano and Rigobon (2001), Hausmann and Rigibon (2002), Leite and Weidmann (2002), and Sala-i-Martin and Subramanian (2003). For a recent survey, see Rossner (2006).

${ }^{3}$ Cameroon's oil output in 2006 was just 4 percent of oil output in Nigeria, Africa's largest oil producer.
} 

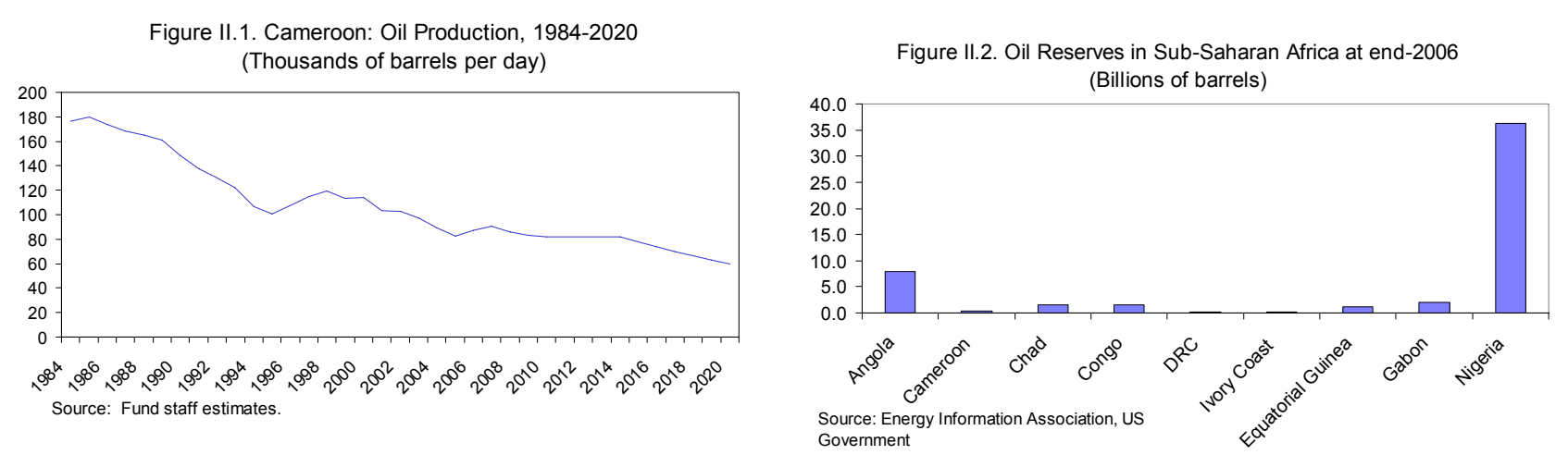

5. As oil production grew rapidly in the late 1970s and early 1980s, Cameroon pursued an expansionary fiscal policy that proved unsustainable and eventually contributed to a deep economic crisis (Table II.1 and Figure II.3). From 1976 to 1985, inflation-adjusted government spending rose by an average of 15 percent a year, contributing to strong economic growth. By the second half of the 1980s, however, oil output and international oil prices began to decline, bringing the oil boom to an end. In response, the government made fiscal adjustments (mainly cuts in investment) and pursued limited structural reforms. These steps, however, were insufficient to keep Cameroon from entering a deep recession, which lasted from 1987 until the mid-1990s. In that period per capita income declined more than 40 percent, and Cameroon accumulated a large public debt and payment arrears. By the early 1990s, it was clear that fiscal adjustment and structural reform alone could not restore competitiveness. In the light of similar difficulties in neighboring countries, the CFA franc was devalued by 50 percent in early 1994.

\section{Much of the poverty that arose during the crisis years has persisted despite} improved macroeconomic performance. (Table II.1 and Figure II.3). From 1995 to 2006, GDP growth averaged 4 percent, inflation was generally low, and the fiscal accounts, on average, were close to balance. Thanks to HIPC-related relief, the heavy external debt burden that accumulated in the early 1990s fell to only 5 percent of GDP in 2006. Yet, by the authorities' estimates, about 40 percent of households continue to live below the poverty line. Further, Cameroon's score on the UNDP's human development index - an aggregate measure based on such indicators as life expectancy, adult literacy, primary school enrollment, and per capita income — has yet to rebound to its pre-crisis level.

\section{The Permanent Income Approach}

\section{The permanent income approach is often used to develop a fiscal framework for} countries with nonrenewable resources. Under this approach, fiscal revenue from both oil and nonoil resources is taken as given, and the utility of government spending is seen as akin to the utility of a private agent spending on consumption. Accordingly, the government chooses the spending path that maximizes the utility of the representative infinitely lived individual, up to the amount that can be accommodated within the government's budget 
constraint. ${ }^{4}$ Based on this premise, the permanent income approach recommends that governments fully smooth primary fiscal spending over time, setting it equal to permanent income (i.e., the constant level of fiscal revenue that can be generated from both oil and nonoil revenue sources), minus interest payments on inherited public debt. ${ }^{5,6}$ The permanent income approach has several attractive features: First, by tying spending to the utility of the representative infinitely lived household, it ensures that wealth is shared among generations. Second, by integrating the government's budget constraint, it ensures that spending is sustainable. Third, by smoothing expenditure, it helps minimize the likelihood of boom-bust cycles.

Table II.1. Cameroon: Key Economic and Financial Indicators (Percent of GDP, unless otherwise noted)

\begin{tabular}{|c|c|c|c|c|c|}
\hline & $1981-85$ & $1986-90$ & 1991-95 & 1996-2000 & 2001-06 \\
\hline GDP (annual growth, percent) & 9.4 & -2.2 & -1.8 & 4.7 & 3.6 \\
\hline Oil GDP (annual growth, percent) ${ }^{1}$ & 25.1 & -6.4 & -12.0 & 1.4 & -3.9 \\
\hline Total fiscal revenue (excl. grants) & 21.1 & 15.2 & 11.9 & 13.1 & 16.9 \\
\hline Oil revenue $^{2}$ & 7.7 & 5.5 & 3.4 & 3.4 & 5.1 \\
\hline Total fiscal expenditure & 20.5 & 20.9 & 18.4 & 15.5 & 15.6 \\
\hline Current expenditure & 10.6 & 12.6 & 16.5 & 13.7 & 13.5 \\
\hline Capital expenditure & 9.8 & 8.3 & 1.9 & 1.8 & 2.1 \\
\hline Primary expenditure $^{2}$ & 19.4 & 19.6 & 13.5 & 10.6 & 13.5 \\
\hline Overall balance (excl. grants) & 0.7 & -5.7 & -6.5 & -2.4 & 1.3 \\
\hline \multicolumn{6}{|l|}{ Memorandum items: } \\
\hline Intl. oil price (US\$ per barrel) & 30.2 & 17.6 & 17.7 & 19.8 & 38.9 \\
\hline Oil production (thousands of barrels per day) ${ }^{2}$ & 178.1 & 163.4 & 119.5 & 113.9 & 93.8 \\
\hline Fiscal expenditure (inflation adjusted annual growth, percent) & 20.0 & -5.9 & -8.4 & 7.1 & 1.2 \\
\hline Real effective exchange rate (annual change, percent) & -1.8 & 3.7 & -7.6 & 0.3 & 2.1 \\
\hline Per-capita GDP (annual growth, percent) & 6.4 & -5.0 & -4.4 & 2.5 & 1.6 \\
\hline $\begin{array}{l}\text { Sources: Cameroon authorities, IFS, and IMF staff estimates. } \\
{ }^{1} \text { Average for } 1976-80 \text { reflects data from } 1979 \text { onwards. } \\
{ }^{2} \text { Average for } 1981-85 \text { reflects data from } 1984 \text { onwards. } \\
{ }^{3} \text { Average for } 1991-96 \text { reflects data from } 1992 \text { onwards. }\end{array}$ & & & & & \\
\hline
\end{tabular}

\footnotetext{
${ }^{4}$ The notion of a representative infinitely lived individual is used to simplify the analysis. It imposes the assumptions that all individuals have identical preferences, and that they value their children's consumption as much as their own (future) consumption.

${ }^{5}$ This result mirrors Friedman's finding that a household with uneven consumption maximizes its utility by setting consumption equal to its permanent income (Friedman 1957).

${ }^{6}$ The permanent income approach is most often applied in ways that ignore uncertainty and the costs of adjusting fiscal spending levels. Engel and Valdès (2000) show how uncertainty changes results. Leigh and Olters (2006) show how adjustment costs change results.
} 
Figure II.3. Cameroon: The Crisis of the Late 1980s and Early 1990s and its Aftermath
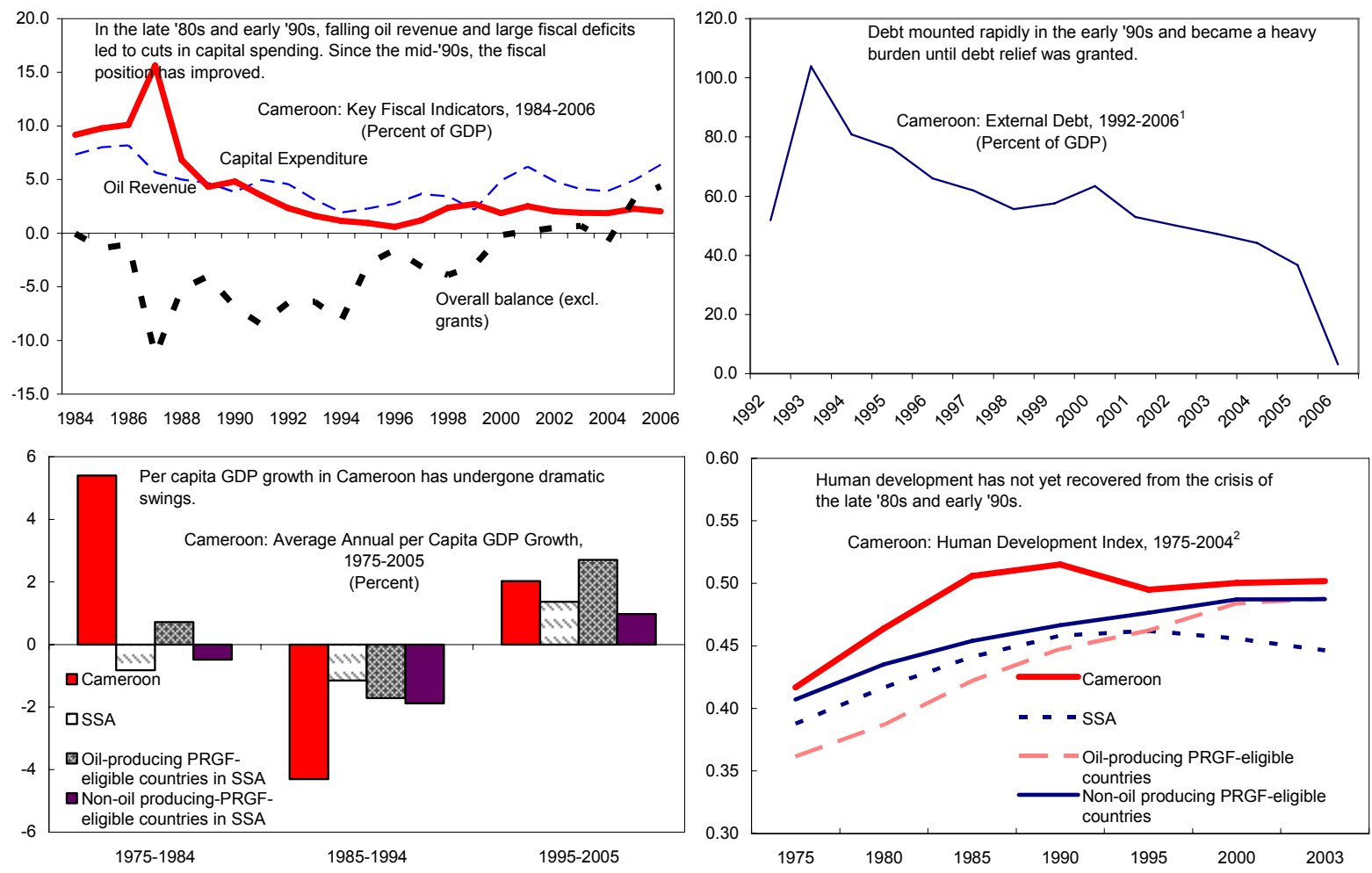

Sources: IMF staff estimates and United Nations Development Program.

${ }^{1}$ Through 2000, fiscal years July-June. Fiscal year 1993 includes 1994 devaluation.

${ }^{2}$ Includes only countries for which data are available for all periods.

\section{It is important to note, however, that this approach has been criticized as overly} restrictive when applied to countries with important investment needs. The premise of the approach - that government spending is purely consumptive - fails to consider domestic investment, reflecting the finding that much investment spending in sub-Saharan Africa in the past has been of low quality and thus had little investment character. ${ }^{7}$ However, in countries with very limited physical and human capital, the returns of investing in infrastructure, education, or health services - in the form of enhanced productivity and growth - could in principle exceed the returns of investing in financial assets. For developing countries, it may thus be optimal to let spending temporarily exceed the sustainable threshold (Takizawa, Gardner, and Ueda 2004). The omission of investment spending from the permanent income approach is an important caveat when interpreting the results presented in this paper.

\footnotetext{
${ }^{7}$ See, for example, Sala-i-Martin and Subramanian (2003), who find that poor quality spending explains part of Nigeria's weak economic performance in the past 30 years.
} 


\section{Application to Cameroon and Results}

9. A common variant of the permanent income approach is applied to Cameroon. In this variant, the utility of the representative individual depends on the ratio of primary spending to nonoil GDP, with the optimal policy being to keep that ratio constant at the sustainable level (permanent income minus interest payments on inherited debt adjusted for nonoil GDP growth). ${ }^{8}$ Box II.1 outlines the main assumptions underpinning the application.

\section{Box II.1. Applying the Permanent Income Approach to Cameroon: Main Assumptions}

1) Cameroon exploits all its proven oil reserves, half of its probable oil reserves, half of its proven gas reserves, and a quarter of its probable gas reserves.

2) The price of Cameroonian crude remains at a discount of 6 percent, or US\$ 3.5 per barrel, relative to World Economic Outlook projections, as observed in 2004-06.

3) Fiscal oil revenue remains at about 65 percent of oil GDP, as observed in 2004-06.

4) Fiscal nonoil revenue rises by 0.1 percentage point per year on average during 2007-21 - from 13.5 percent of nonoil GDP to 15 percent - and is constant thereafter.

5) Real nonoil GDP grows by 3.8 percent per year, as observed in 2004-06.

6) The real interest rate is 4.2 percent, exceeding the 3.2 percent real interest rate average observed for U.S. government bonds in the past two decades. ${ }^{9}$

\section{The application suggests that Cameroon could sustain a moderate fiscal}

expansion. Under the baseline scenario, which assumes a gradual increase in nonoil revenue (see Box II.1), Cameroon could permanently sustain primary spending of 15.4 percent of nonoil GDP each year from 2007 on. This would represent a moderate fiscal expansion relative to 2006, when primary spending (excluding foreign-financed investment) was 15.1 percent of nonoil GDP. ${ }^{10}$ Given the assumed gradual increase in nonoil revenue through 2021, the nonoil primary deficit would decline steadily - from 1.8 percent of nonoil GDP in

\footnotetext{
${ }^{8}$ Applications of this variant are numerous and include Davoodi (2002) for Kazakhstan, Baunsgaard (2003) for Nigeria, Danninger et al. (2005) for Azerbaijan, Bailen and Karamenko (2004) for Iran, Velculescu and Rizavi (2005) for Trinidad and Tobago, Segura (2006) for São Tomé and Príncipe, Leigh and Olters (2006) for Gabon, and Olters (forthcoming) for all sub-Saharan African oil producers.

${ }^{9}$ The difference is intended to reflect two factors: the surcharge Cameroon would have to pay on its debt given its lower sovereign rating as well as the margin Cameroon could hope to earn if it invested part of its savings in international stocks instead of prime debt titles.

${ }^{10}$ The permanent income approach determines the level of sustainable spending that can be financed from domestic sources (oil and nonoil revenue). To ensure comparability between the results of the permanent income approach and 2006 spending figures, foreign-financed investment was excluded from the 2006 data.
} 
2007 to 0.4 percent in 2021 - and remain constant thereafter. The appendix provides further details on the size of revenue components as well as the evolution of spending components and the fiscal balance.

11. This result, however, should be interpreted with caution, especially given its sensitivity to changes in certain parameters (Table II.2 and Figure II.4). Specifically, the level of sustainable spending is

- Highly sensitive to changes in nonoil revenue. If nonoil revenue stayed at its 2006 level of 13.5 percent of nonoil GDP, primary spending would need to be 1.5 percent of nonoil GDP lower than in the baseline for it to be sustainable. In such a scenario, the government would need to reduce spending to 14 percent of nonoil GDP from 2007 on, implying a fiscal contraction of 1.1 percent of nonoil GDP relative to 2006 spending.

- Moderately sensitive to changes in oil prices and oil production volumes. For example, a US $\$ 10$ variation in the per-barrel price would change the level of sustainable primary spending by only 0.1 percent of nonoil GDP. Higher or lower production, within reasonable limits, would change the spending estimates by less than 0.4 percent of nonoil GDP. The lesser sensitivity of the level of sustainable spending with respect to changes in oil prices and oil production volumes is because Cameroon's oil sector, and thus the oil sector's share of total revenue, is relatively small.

- Moderately sensitive to changes in real interest rates. For example, in response to an interest rate variation of 0.25 percentage point, the level of primary spending that could be sustained would change by 0.2 percentage point of nonoil GDP. Again, the moderate sensitivity of the results to changes in interest rates reflects the small size of Cameroon's oil sector - and hence the correspondingly small size of financial assets that can be built by saving some of the oil revenue. ${ }^{11}$

\footnotetext{
${ }^{11}$ If Cameroon were to set spending to the sustainable level, it would build up a positive net financial asset position by saving some of the oil revenue, see the appendix.
} 


\section{Table II.2. Cameroon: Sensitivity Analysis at a Glance}

Baseline vs. Alternative Scenarios

\begin{tabular}{|lc|}
\hline \multicolumn{2}{|c|}{$\begin{array}{c}\text { Sustainable Primary Fiscal Spending } \\
\text { (Percent of nonoil GDP) }\end{array}$} \\
Baseline Scenario & 15.4 \\
Interest rate 0.25\% higher & 15.7 \\
Interest rate 0.25 \% lower & 15.2 \\
Nonoil revenue constant at 2006 value & 14.0 \\
Oil prices US\$ 10 per barrel higher & 15.5 \\
Oil prices US\$ 10 per barrel lower & 15.3 \\
Nonoil GDP growth 0.25\% point higher & 15.2 \\
Nonoil GDP growth 0.25 \% point lower & 15.7 \\
\hline
\end{tabular}

Source: IMF staff estimates.

Figure II.4. Cameroon: Sustainable Nonoil Primary Balance, 2004-54 (Percent of nonoil GDP)

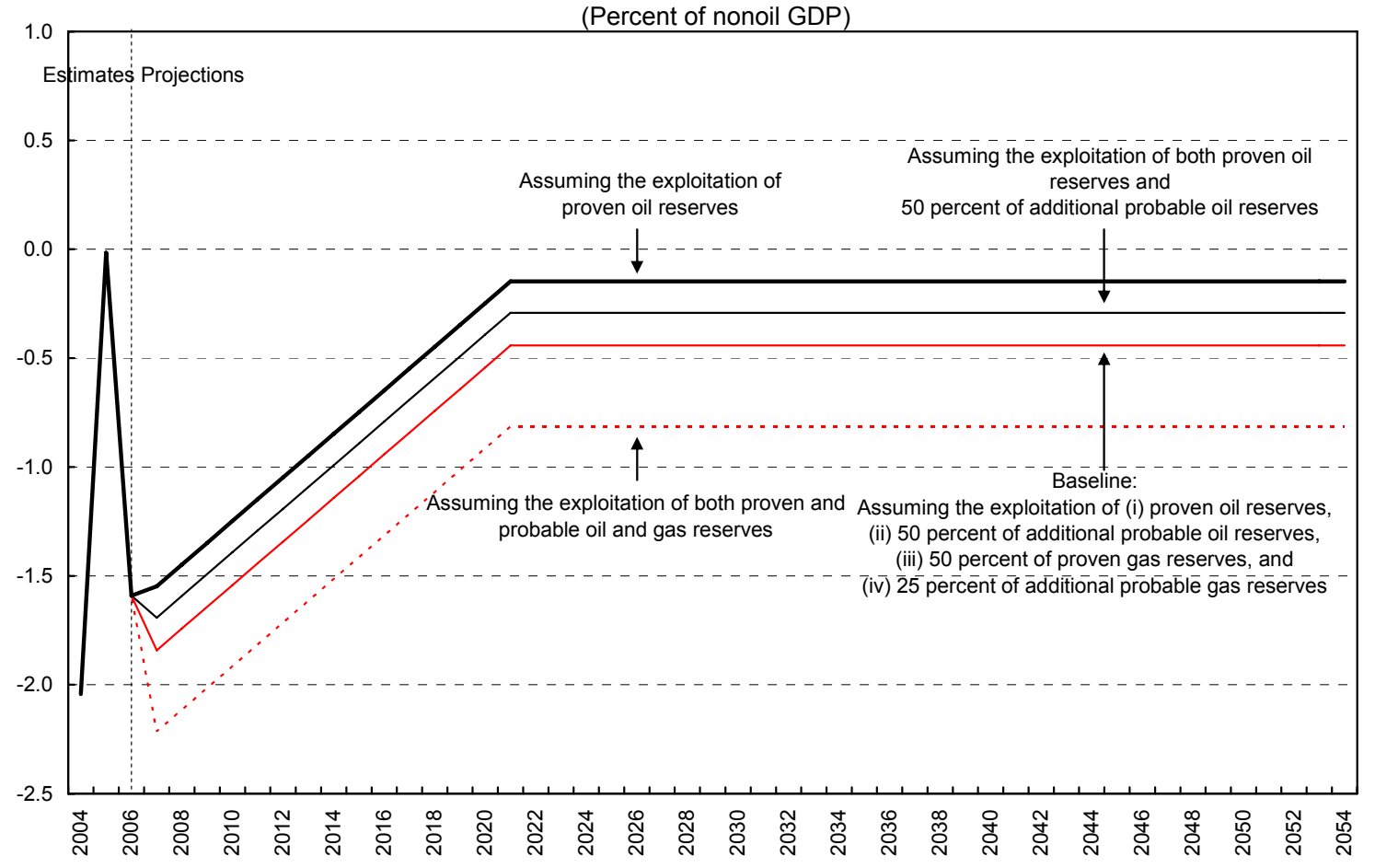

Sources: Cameroonian authorities; and IMF staff estimates and calculations. 


\section{References}

Bailen, J., and V. Karamenko, 2004, "Issues in Medium-Term Management of Oil Wealth," in Islamic Republic of Iran: Selected Issues, IMF Country Report 04/308 (Washington: International Monetary Fund), pp. 22-36.

Barnett, S., and R. Ossowski, 2003, “Operational Aspects of Fiscal Policy in Oil-Producing Countries," in Fiscal Policy Formulation and Implementation in Oil-Producing Countries, ed. by J. M. Davis, R. Ossowski, and A. Fedelino (Washington: International Monetary Fund), pp. 45-81.

Baunsgaard, T., 2003, "Fiscal Policy in Nigeria: Any Role for Rules?" IMF Working Paper 03/155 (Washington: International Monetary Fund).

Danninger, S., E. Le Borgne, J. Wakemann-Linn, N. Hobdari, C. Aturupane, and K. Gvenetadze, 2005, Managing Oil Wealth: The Case of Azerbaijan (Washington: International Monetary Fund).

Davoodi, H., 2002, “Assessing Vulnerability, Fiscal Sustainability, and Fiscal Stance in a Natural Resource-Rich Country," in Republic of Kazakhstan: Selected Issues and Statistical Appendix (Washington: International Monetary Fund), pp. 7-31.

Engel, E., and R. Valdés, 2000, “Optimal Fiscal Strategy for Oil Exporting Countries,” IMF Working Paper 00/118 (Washington: International Monetary Fund).

Friedman, M., 1957, A Theory of the Consumption Function (Princeton, NJ: Princeton University Press).

Hausmann, R., and R. Rigobon, 2002, “An Alternative Interpretation of the 'Resource Curse': Theory and Policy Implications,” NBER Working Paper No. 9424 (Cambridge: National Bureau of Economic Research).

Leigh, D., and J. P. Olters, 2006, "Natural Resource Depletion, Habit Formation, and Sustainable Fiscal Policy: Lessons from Gabon,” IMF Working Paper 06/193 (Washington: International Monetary Fund).

Leite, C., and J. Weidmann, 1999, "Does Mother Nature Corrupt? Natural Resources, Corruption, and Economic Growth,” IMF Working Paper 99/85 (Washington: International Monetary Fund).

Manzano, O., and R. Rigobon, 2001, “Resource Curse or Debt Overhang?” NBER Working Paper No. 8390 (Cambridge: National Bureau of Economic Research). 
Olters, J.-P., forthcoming, "Old Curses, New Approaches? Fiscal Benchmarks for OilProducing Countries in Sub-Saharan Africa," IMF Working Paper (Washington: International Monetary Fund).

Rossner, A., 2006, "The Political Economy of the Resource Curse: A Literature Review," University of Sussex Institute of Development Studies Working Paper No. 268 (Sussex: University of Sussex).

Sachs, J., and A. Warner, 1995, "Natural Resource Abundance and Economic Growth," NBER Working Paper No. 5398 (Cambridge: National Bureau of Economic Research).

Sala-i-Martin, S., and A. Subramanian, 2003, "Addressing the Natural Resource Curse: An Illustration from Nigeria," IMF Working Paper 03/139 (Washington: International Monetary Fund).

Segura, A., 2006, "Management of Oil Wealth Under the Permanent Income Hypothesis: The Case of São Tomé and Príncipe," IMF Working Paper 06/183 (Washington: International Monetary Fund).

Takizawa, H., E. Gardner, and K. Ueda, 2004, “Are Developing Countries Better Off Spending Their Oil Wealth Upfront?” IMF Working Paper 04/141 (Washington: International Monetary Fund).

Velculescu, D., and S. Rizavi, 2005, "Trinidad and Tobago: The Energy Boom and Proposals for a Sustainable Fiscal Policy,” IMF Working Paper 05/197 (Washington: International Monetary Fund). 


\section{APPENDIX II.1}

This appendix provides details on the size of revenue components as well as the evolution of spending components and the fiscal balance.

1. Sustainable fiscal spending is calculated according to

$$
g=\bar{\tau}+\frac{r-\gamma}{1+r} \sum_{j=0}^{E_{1}}\left(\frac{1+\gamma}{1+r}\right)^{j}\left(\tau_{t}-\bar{\tau}\right)_{t+j}+\frac{r-\gamma}{1+r} \sum_{j=0}^{E_{2}}\left(\frac{1+\gamma}{1+r}\right)^{j} z_{t+j}-\frac{r-\gamma}{1+\gamma} b_{t-1},
$$

where $g$ is primary government spending over nonoil GDP, $\bar{\tau}$ long-run nonoil revenue over nonoil GDP (assumed at 15 percent under the baseline), $\tau_{t}$ nonoil revenue over nonoil GDP, $z_{t}$ oil revenue over nonoil GDP, $b_{t}$ debt over nonoil GDP, $r$ the real interest rate, $\gamma$ the real growth rate of nonoil GDP, $E_{1}$ the last period before nonoil revenue reaches its long-run level, and $E_{2}$ the last period before oil revenue stops. Equation (1) is a generalization of the formula in Barnett and Ossowski (2003).

2. Accordingly, the level of primary fiscal spending that is sustainable flows from the following four sources (totaling 15.4 percent of nonoil GDP under the baseline):

a) the long-run level of nonoil revenue (under the baseline, 15 percent of nonoil GDP every year);

b) the interest payments on the present value of the shortfall of nonoil revenue relative to its long-run level (under the baseline, the interest rate adjusted for nonoil GDP growth is 0.4 percent per year, the present value of the shortfall of nonoil revenue relative to its longrun level is 10 percent of 2007 nonoil GDP, resulting in interest payments of 0.04 percent of nonoil GDP every year);

c) the interest receipts on the present value of oil revenue (under the baseline, the interest rate adjusted for nonoil GDP growth is 0.4 percent per year, the present value of oil revenue is 1.4 times 2007 nonoil GDP, resulting in interest receipts of 0.6 percent of nonoil GDP every year);

d) the interest payments on inherited public debt (under the baseline, the interest rate adjusted for nonoil GDP growth and for the fact that the debt level to be serviced is that of the preceding year 2006 is 0.4 percent, and the level of inherited debt is 17 percent of 2006 nonoil GDP, resulting in interest payments of 0.07 percent of nonoil GDP every year).

3. Primary spending at the sustainable level of 15.4 percent of nonoil GDP generates a nonoil primary deficit and, initially, an overall fiscal surplus, given substantial initial oil 
revenue. The overall surplus first allows the government to reduce net debt and later build positive net financial assets. The corresponding reduction in interest payments by the government and the eventual receipt of interest payments help offset the decline in oil revenue, as does the increase in nonoil revenue. Eventually, the nonoil primary fiscal deficit improves to 0.4 percent of GDP and the overall fiscal surplus falls to zero (given spending of 15.4 percent of nonoil GDP, nonoil revenue of 15 percent of nonoil GDP, oil revenue of zero, and interest receipts of 0.4 percent of nonoil GDP). 


\section{Promoting FinANCIAL Intermediation: ISSUES AND REFORM ProsPECTS ${ }^{1}$}

\section{A. Introduction}

1. A developed financial system stimulates economic growth. The economic literature $^{2}$ provides ample evidence that improvements in financial systems contribute to increased efficiency in resource allocation, and hence growth. Savings are channeled into more productive uses, facilitating investment diversification as well as risk management for savers and investors. Furthermore, a large access to financial services for small and medium size enterprises and lower-income households improves their ability to benefit from investment opportunities, and access better quality health and education services. Empirical studies have also shown that financial development reduces income inequality. ${ }^{3}$

2. The role of the financial sector in fostering nonoil sector activities has been limited in Cameroon. Financial depth, as measured by the ratio of broad money to GDP, has been lower in Cameroon than in many other countries in sub-Saharan Africa. The financial system's ability to attract long-term savings and promote credit creation has been constrained by a number of factors, contributing in part to relatively lower growth performance in Cameroon than in sub-Saharan Africa on average over the past twenty years or so.

3. This chapter discusses impediments to financial development in Cameroon. The main conclusions are that greater access to financial services, particularly for small and medium size enterprises and households, has been limited by several factors, including the decline in bank penetration, cumbersome administrative procedures, inefficiencies in the financial system's operating environment, particularly in the judiciary, and difficulties in assessing credit risk. The latter is mainly due to the lack of a rating system and poor accounting practices. Measures at the national and regional levels would be needed to remove these obstacles and enhance the financial system's support to nonoil economic growth. ${ }^{4}$

\section{B. Financial System Overview}

4. Cameroon's financial system, the largest in the Economic Community of Central African States (CEMAC), continues to be dominated by banks (Tables III.1 and III.2). Cameroon accounts for about 55 percent of CEMAC's financial assets, the bulk of which is from the banking sector. Despite its rapid growth in recent years, the microfinance sector

\footnotetext{
${ }^{1}$ Prepared by Malangu Kabedi-Mbuyi and Romain Veyrune.

${ }^{2}$ See Allen and Ndikumana (2000) for a review of the literature.

${ }^{3}$ Claessens (2005).

${ }^{4}$ Lack of reliable data on most financial institutions hampers a comprehensive analysis of the financial system at this stage. Consequently, the chapter focuses mostly on the banking sector.
} 
remains marginal. According to estimates, it accounts for less than 5 percent of the financial system's assets in Cameroon.

Table III.1. Cameroon - Financial System Structure, 2005

\begin{tabular}{|c|c|c|c|c|c|}
\hline & \multicolumn{2}{|c|}{ Number of } & \multicolumn{3}{|c|}{ Financial System Assets } \\
\hline & Institutions & Branches & CFAF billion & Percent of Total & Percent of GDP \\
\hline Commercial banks & 10 & 104 & 1741.1 & 84.4 & 19.6 \\
\hline Local & 4 & 37 & 565.7 & 27.4 & 6.4 \\
\hline Foreign & 6 & 67 & $1,175.4$ & 56.9 & 13.2 \\
\hline Nonbank financial institutions & 12 & 27 & 130.0 & 6.3 & 1.5 \\
\hline Microfinance institutions & 714 & 714 & 95.0 & 4.6 & 1.1 \\
\hline Insurance companies & 24 & 0 & 98.0 & 4.7 & 1.1 \\
\hline Total financial sector & 760 & 845 & $2,064.1$ & 100.0 & 23.2 \\
\hline
\end{tabular}

Source: COBAC.

Table III.2. Cameroon's Position in CEMAC Financial System, 2005

\begin{tabular}{|c|c|c|c|c|c|c|}
\hline & \multicolumn{3}{|c|}{ Number of Institutions } & \multicolumn{3}{|c|}{ Assets } \\
\hline & CEMAC & Cameroon & $\begin{array}{r}\text { Cameroon } \\
\text { share } \\
\text { (percent) }\end{array}$ & CEMAC & Cameroon & $\begin{array}{r}\text { Cameroon } \\
\text { share } \\
\text { (percent) }\end{array}$ \\
\hline Banks & 33 & 10 & 30.3 & $3,132.3$ & $1,741.1$ & 55.6 \\
\hline Private & 31 & 10 & 32.3 & $3,020.0$ & $1,741.1$ & 57.7 \\
\hline Local & 8 & 4 & 50.0 & 869.0 & 565.7 & 65.1 \\
\hline Foreign & 23 & 6 & 26.1 & $2,151.0$ & $1,175.4$ & 54.6 \\
\hline Government & 2 & 0 & 0.0 & 112.3 & 0.0 & 0.0 \\
\hline Nonbank financial institutions & 17 & 12 & 70.6 & 215.2 & 130.0 & 60.4 \\
\hline Microfinance institutions & 1,018 & 714 & 70.1 & 133.0 & 95.0 & 71.4 \\
\hline Insurance companies & 36 & 24 & 66.7 & 164.0 & 98.0 & 59.8 \\
\hline Total financial sector & 1,104 & 760 & 68.8 & $3,644.5$ & $2,064.1$ & 56.6 \\
\hline
\end{tabular}

Source: COBAC, 2006 Regional FSAP.

\section{Cameroon is one of the few CEMAC countries with minimal public sector}

participation in the banking sector (Figure III.1). The public sector's stake in the banking sector declined markedly after banks were restructured in the early 1990s. Before the banking sector crisis, the government was a shareholder in six out eight commercial banks and had majority ownership in two of the banks. By end-2005, the government held 35 percent stake in one bank and less than 30 percent in two banks. 


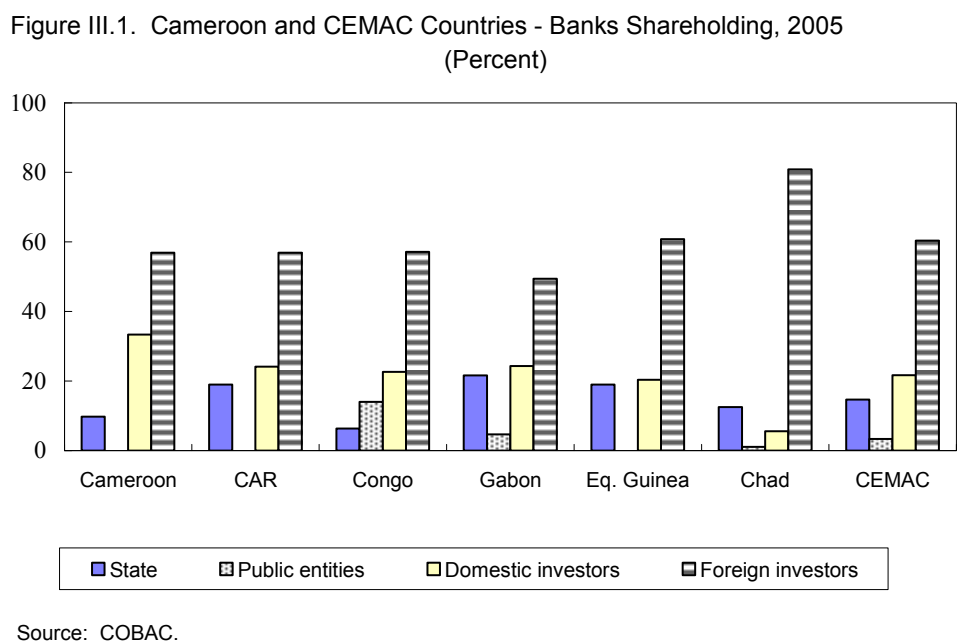

6. The banking sector's concentration is moderate, and the lowest in CEMAC. Two out of eight banks in 1999 held half the sector's deposits and credit; four out of ten banks in 2005 accounted for about three-quarters of deposits and credit (Figure III.2). ${ }^{5}$ Furthermore, the Hirschman-Herfindhal Index (HHI), which measures concentration, stood at 1,019 in 2005 , and was higher than 1,800 in other CEMAC countries. ${ }^{6}$

7. Microfinance institutions (MFIs) seem to have expanded rapidly in recent years, but remain marginal players. Their deposits and credit are estimated to have more than doubled in 2001-05. Deposits in 2005 were 7 percent of commercial bank deposits, up from 4 percent in 2001 . The increase in microfinance activity partly reflects the banking sector's inadequate response to demand for financial services from small and medium size enterprises (SMEs) and households. MFIs' activity also benefited from the decline in bank penetration after the sector's restructuring in the early 1990s, which resulted in higher branch concentration in major cities. The microfinance sector, however, remains marginal, and has limited capacity to finance long-term investment. A regional regulatory framework for MFIs was adopted in 2002. Under the framework, some 300 unlicensed institutions were closed at end-2005. Guidelines for MFIs' financial reporting, and prudential norms for the sector are under preparation.

\footnotetext{
${ }^{5}$ Three of the largest banks in the sector are subsidiaries of foreign banks.

${ }^{6}$ The Hirschman-Herfindhal Index is calculated as the sum of square market shares of banks. The HHI indicates: an unconcentrated marked when it is below 1,000; moderate concentration when it is higher than 1,000 but less than 1,800; and high concentration when it is above 1,800.
} 
Figure III.2. Cameroon - Credit and Deposits Structure, 2005
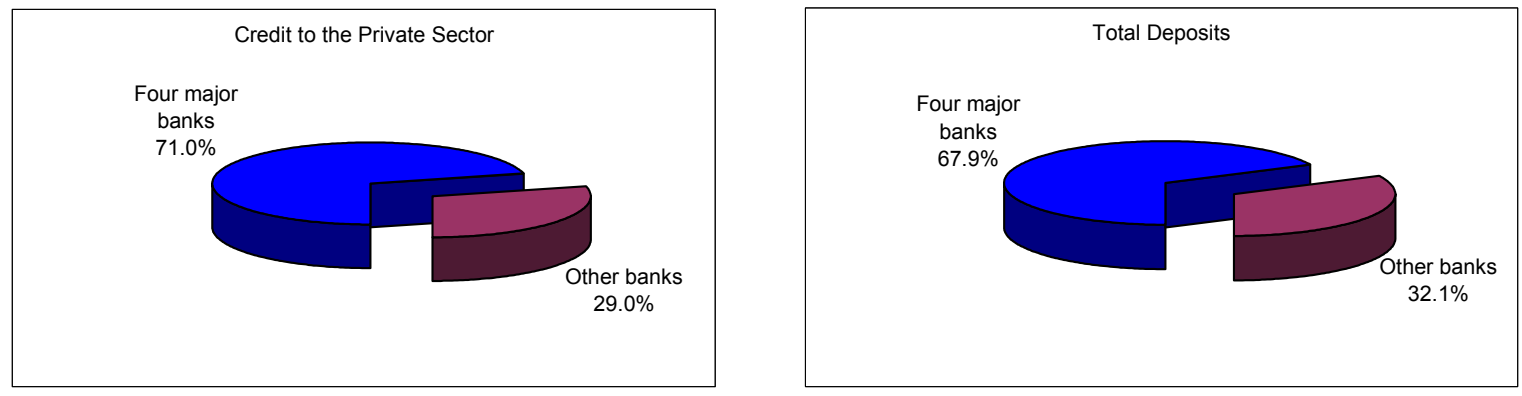

Source: BEAC.

8. Other financial market participants include insurance companies, specialized nonbank institutions, and the Douala Stock Exchange (DSX). The insurance sector offers a limited range of services, and many companies face solvency problems. In recent years, the regional supervisory agency withdrew operating licenses for five companies. The postal and savings bank (CAMPOST) and the housing bank (Credit Foncier) are being restructured (Box III.1). Other specialized institutions offer leasing services, loan guarantees, and microcredit. The public pension fund (CNPS) covers maternity, workers' compensation, and pension payments. The DSX has been idle since it was established in 2002. At end-2006, only one company was listed, and trading has been minimal. ${ }^{7}$

\section{Banking Sector Performance}

9. The banking sector's soundness has improved somewhat, though the sector remains vulnerable to shocks. Observance of regional prudential norms improved in the last two years (Table III.3). Nonetheless, as in other CEMAC countries, Cameroonian banks' compliance with the capital adequacy ratio (CAR), and with the limit on single large exposure, remains weak. Given the scarcity of lending opportunities, banks have concentrated credit on a few large creditworthy corporate clients in the non-oil sector. Stress tests indicate that (i) credit concentration has made the banking system vulnerable to credit risks; (ii) the system is vulnerable to interest rate risk; and (iii) excess liquidity would allow the system to weather large deposit withdrawals.

10. The share of nonperforming loans banks' portfolio has declined markedly. Gross nonperforming loans (NPL) declined from 40 percent of total credit in 1995 to $12 \frac{1}{2}$ percent in 2005 (Figure III.3), mostly reflecting the transfer of important outstanding claims to the loan recovery agency in the context of commercial banks restructuring. The substantial reduction in government domestic payment arrears in recent years also contributed to the

\footnotetext{
${ }^{7}$ A regional stock exchange was established in Libreville (Gabon) in 2003. This may have generated increased competition for the DSX, in view of the thinness of the CEMAC market.
} 
improvement. ${ }^{8}$ In addition, provisioning has improved, thus strengthening the quality of banks' portfolio (See Table III.3).

\begin{tabular}{|c|c|c|c|c|}
\hline \multicolumn{5}{|c|}{$\begin{array}{c}\text { Table III.3. Cameroon: Banking System Indicators } \\
\text { (Units indicated) }\end{array}$} \\
\hline & 2003 & 2004 & 2005 & 2006 \\
\hline \multicolumn{5}{|l|}{ Violations of main prudential ratios ${ }^{1}$} \\
\hline Capital adequacy & 1 & 3 & 5 & 4 \\
\hline Liquidity $^{2}$ & 0 & 2 & 0 & 0 \\
\hline Fixed-asset coverage ${ }^{3}$ & 2 & 4 & 5 & 6 \\
\hline Maturity transformation ${ }^{4}$ & 3 & 5 & 4 & 4 \\
\hline Minimum capital $^{5}$ & 1 & 2 & 2 & 2 \\
\hline Limit on single large exposure $^{6}$ & 7 & 8 & 7 & 6 \\
\hline \multicolumn{5}{|l|}{ Quality of loan portfolio } \\
\hline Nonperforming loans (percent of gross loans) & 13.9 & 13.1 & 12.6 & 12.4 \\
\hline Provisions (percent of nonperforming loans) & 81.2 & 85.3 & 85.4 & 89.5 \\
\hline \multicolumn{5}{|c|}{$\begin{array}{l}\text { Sources: COBAC, and staff calculations. } \\
{ }^{1} \text { Number of banks. There were } 9 \text { banks through } 2004,10 \text { in } 2005 \text {, and } 11 \text { in } 2006 . \\
2 \text { Short-term assets (up to one month remaining maturity) over short-term liabilities } \\
\text { (up to one month remaining maturity). } \\
{ }^{3} \text { Net capital and other permanent resources over fixed assets. } \\
{ }^{4} \text { Long-term assets (more than five years) over long-term liabilities (more than five years). } \\
{ }^{5} \text { CFAF } 1 \text { billion for Cameroon. } \\
{ }^{6} \text { Single large exposure is limited to } 45 \text { percent of capital. }\end{array}$} \\
\hline
\end{tabular}

${ }^{8}$ Payment on domestic debt in 2005-06 totaled CFAF 560.7 billion, including CFAF 66 billion to commercial banks. 


\section{Box III.1. Financial Sector Reforms, 1989-2006}

In the late 1980s, Cameroon financial sector experienced a severe crisis. The banking sector was undermined by the difficult economic environment, weak judicial system, poor management, excessive risk concentration, weak supervisory framework, and government interference in banks' lending policies. These factors led to liquidity and solvency problems in the sector. A number of non-bank financial institutions as well as insurance companies were also in a critical position (2000 FSAP).

The reform package put in place in 1989 gave priority to the banking sector. During the initial phase (1989-1992), reform measures included liquidation, restructuring and privatization. Their cost amounted to some CFAF 600 billion, financed mostly by shareholders and creditors, debt compensation, and cancellation of public enterprises deposits. Government participation was financed through an advance from the regional central bank (BEAC) and a bilateral structural adjustment loan. At the end of this phase, however, a number of banks remained undercapitalized and the quality of banks' portfolio had not improved. As a result, by end1995, the five largest banks, accounting for almost three-quarters of the banking sector's assets were technically insolvent, and about half of loans to private sector was nonperforming. The second phase of reforms (1995-June 1997), therefore, comprised further liquidations, recapitalizations, and the issuance of government securities on its debt to commercial banks (2000 FSAP).

A third phase of reforms was initiated in 2004. It covers mostly non bank financial institutions. In 2004, the authorities liquidated two insolvent institutions (Caisse d'Epargne Postale, SONAPOSTE), and put in place the savings and postal bank (CAMPOST). However, the latter became illiquid in 2005, and a reform plan for its rehabilitation was adopted. The plan includes the setting up of a dedicated account to rebuild liquidity, the recruitment of an international management team, and the separation of universal postal and financial services. The housing credit bank (Credit Foncier du Cameroon) is also under restructuring. Poor management and a high level of non performing loans in the last several years had generated severe financial difficulties. Following an inspection report by COBAC, a restructuring plan was prepared and is being implemented by a new management team appointed in late 2005. The plan calls for cost cutting measures, actions to collect delinquent loans, and enhanced management and accounting processes. 

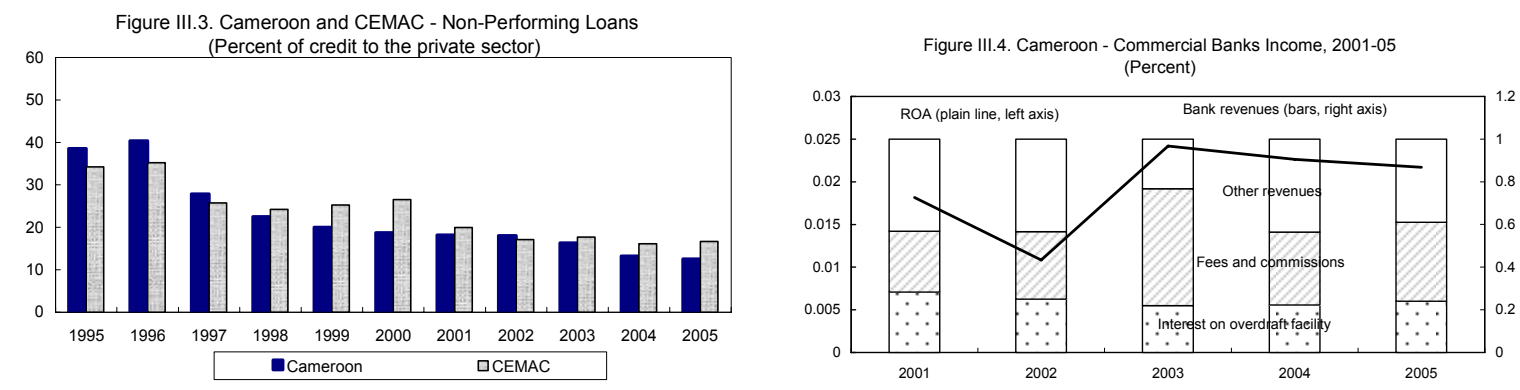

Source: COBAC.

Source: COBAC

11. The banking sector profitability has improved. The return on assets (ROA) averaged 2.2 percent in 2005, up from 1.8 percent in 2001; meanwhile, the sector's return on equity averaged 25 percent, compared with 17 percent, on average, in CEMAC. Banks' revenues are only partly based on maturity transformation. Interest earnings, excluding that on overdraft facilities, make up less than half of total revenue, while fees and commissions continue to be an important source of revenue (Figure III.4).

12. Financial intermediation, however, is lower in Cameroon than most other subSaharan Africa (SSA) countries, though it compares favorably with other CEMAC countries (Figures III.5, III.6, and III.7). In 2005 the ratio of broad money (M2) to GDP, a measure of financial intermediation depth, stood at 17 percent of GDP, compared with 27 percent in Benin, and 44 percent, on Table III.4. Cameroon and Comparator Countries - Selected Financial Indicators average, in SSA. ${ }^{9}$ Credit to the private sector, at some 9 percent of GDP, is also low, and has only marginally increased in the past decade. The ratio of quasimoney (M1) to $\mathrm{M} 2$ remains high, reflecting the financial system's difficulty in attracting financial savings and promoting capital accumulation (Table III.4).

\begin{tabular}{|c|c|c|c|c|c|c|c|c|}
\hline & \multicolumn{2}{|c|}{ M2 } & \multicolumn{2}{|c|}{ Credit to Private Sector } & \multicolumn{2}{|c|}{ Deposits } & \multicolumn{2}{|c|}{ M1/M2 (percent) } \\
\hline & 1995 & 2005 & 1995 & 2005 & 1995 & 2005 & 1995 & 2005 \\
\hline Cameroon & 13.8 & 17.0 & 7.9 & 9.4 & 11.6 & 13.9 & 50.8 & 45.1 \\
\hline Benin & 22.9 & 27.4 & 7.4 & 16.2 & 17.9 & 17.7 & 34.7 & 29.2 \\
\hline Botswana & 20.3 & 27.8 & 11.8 & 18.9 & 18.3 & 26.3 & 69.1 & 72.8 \\
\hline Burkina Faso & 24.0 & 18.8 & 6.7 & 16.0 & 12.8 & 13.5 & 24.9 & 36.7 \\
\hline Gabon & 14.5 & 18.4 & 7.9 & 8.3 & 10.4 & 14.0 & 39.0 & 37.1 \\
\hline Ghana & 21.6 & 28.8 & 5.1 & 15.4 & 14.5 & 20.4 & 44.8 & 47.6 \\
\hline Kenya & 32.0 & 38.7 & 19.4 & 24.8 & 27.0 & 33.5 & 66.1 & 57.8 \\
\hline Mauritius & 78.7 & 150.2 & 47.6 & 77.6 & 71.6 & 143.3 & 82.5 & 86.4 \\
\hline Nigeria & 16.5 & 20.3 & 10.4 & 15.0 & 10.2 & 15.7 & 34.9 & 41.4 \\
\hline Senegal & 20.6 & 34.2 & 14.6 & 22.8 & 14.2 & 25.6 & 36.8 & 37.9 \\
\hline South Africa & 50.0 & 60.9 & 59.1 & 70.7 & 47.3 & 57.9 & 59.2 & 68.9 \\
\hline Tanzania & 25.1 & 27.7 & 6.7 & 10.0 & 17.0 & 21.8 & 43.5 & 55.3 \\
\hline CEMAC & 14.5 & 14.2 & 7.4 & 6.2 & 9.7 & 10.0 & 36.8 & 32.7 \\
\hline WAEMU & 23.1 & 25.9 & 13.6 & 16.0 & 15.1 & 17.3 & 32.1 & 32.4 \\
\hline
\end{tabular}

\footnotetext{
${ }^{9}$ The SSA average excludes Nigeria and South Africa.
} 
Figure III.5. Cameroon and Comparator Countries - Broad Money and Private Sector Credit (Percent of GDP) 1995

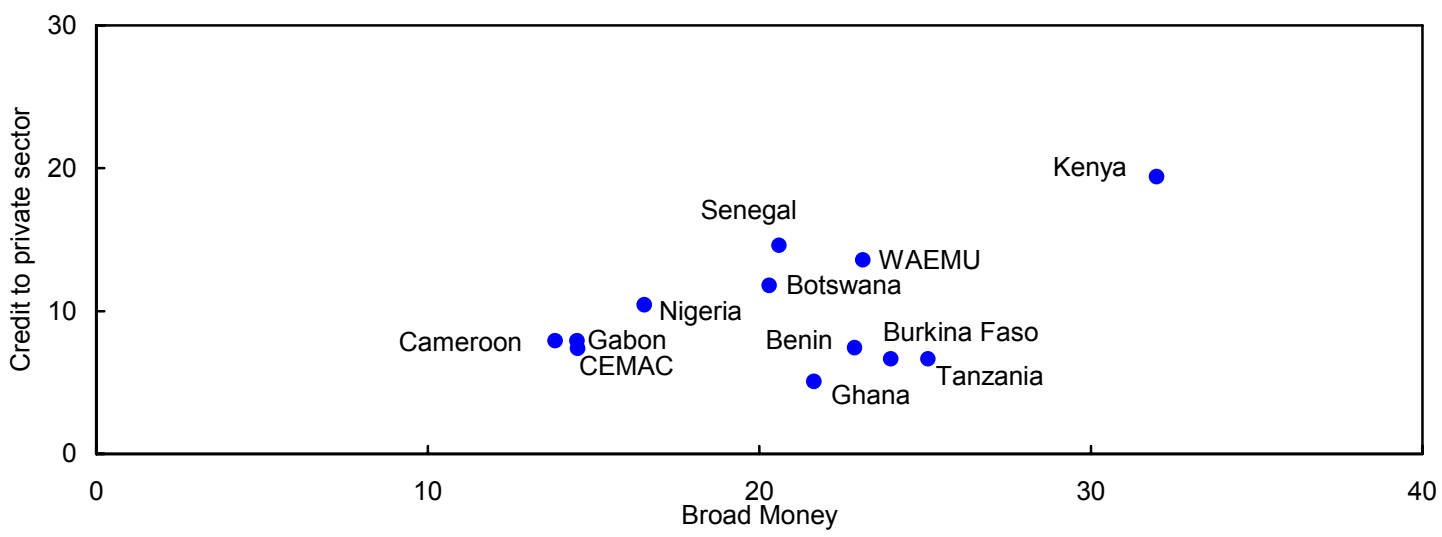

2005

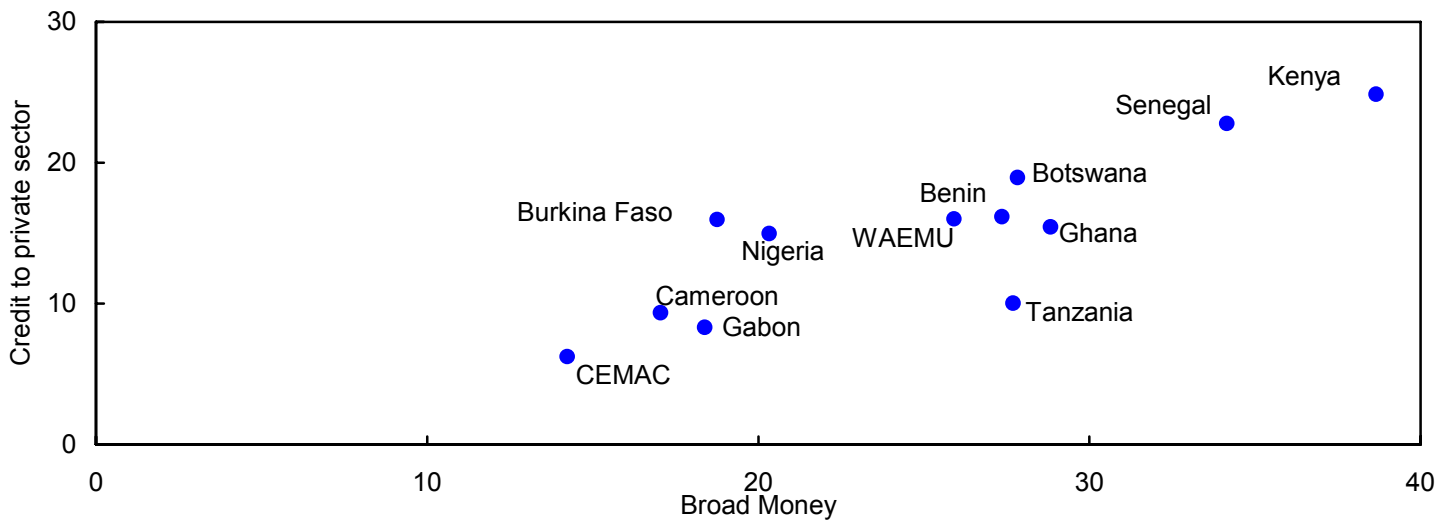

Sources : Cameroonian authorities and IMF staff estimates.

Figure III.6. Cameroon and CEMAC - Broad Money and Credit to Private Sector, 1995-2005 (Percent of GDP)

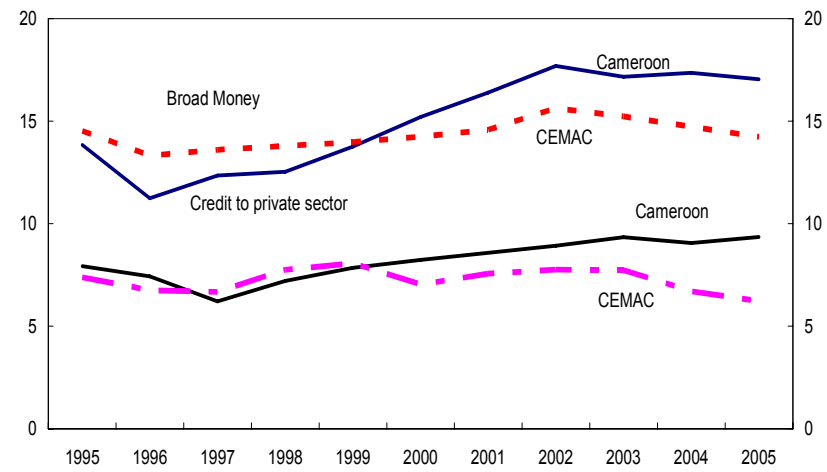

Source: COBAC.
Figure III.7. Cameroon and CEMAC Countries - Credit to Private Sector to GDP, 2005

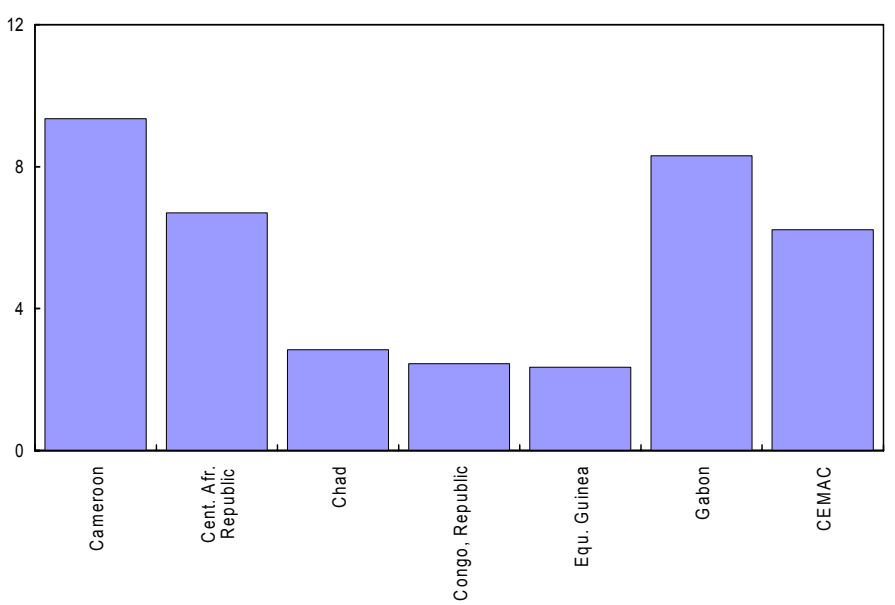




\section{Impediments to Financial Intermediation: Key Issues and Possible Reform Areas}

\section{Physical access to formal banking services is limited and lower than in} comparator countries (Figure III.8). Banks' outreach declined since the restructuring of the sector. Consequently, bank branches are concentrated in major cities, and their number declined from 105 for 8 banks in 1995, to 98 for 10 banks in 2005. Today, only one bank is represented in all the provinces of Cameroon. Recent MFI growth has only partly offset the decrease in bank penetration.

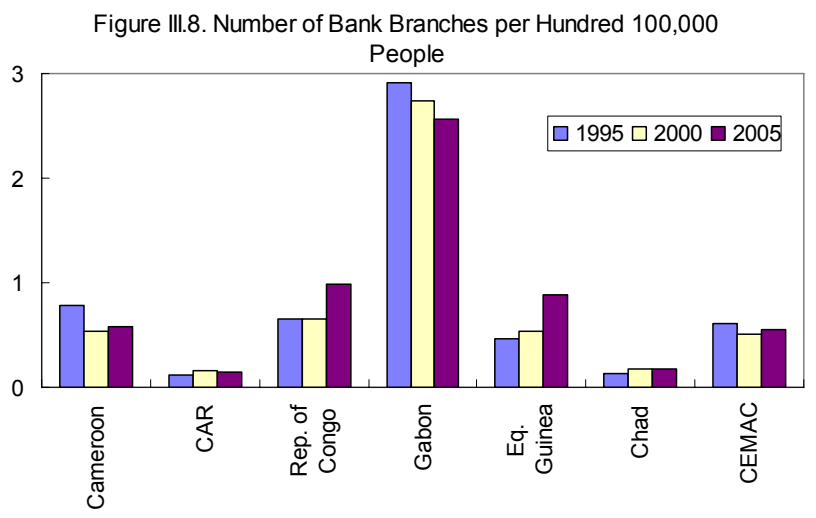

14. Administrative hurdles hamper access to financial services. The minimum amount to open an individual checking or savings account is about US\$ 400. It ranges between US $\$ 300$ and US\$10,000 for corporate accounts. These reportedly excessive requirements are compounded by cumbersome administrative procedures, and sizable maintenance fees and minimum balances. Furthermore, the use of non-cash payment instruments is limited, and cash withdrawals at bank branches is time consuming and remains the commonly used means to access deposited funds. As a result, only 3 percent of the population holds a bank account.

15. The pricing of credit may not be appropriate. The floor on deposit rates and the ceiling on lending rates, set by the BEAC, may be out of line with market fundamentals as pointed out by the 2006 CEMAC regional FSAP (Box III.2). The market for banking services in Cameroon is, in fact, rather segmented with banks competing for creditworthy clients. For these clients, interest rates could be quite low. On the other hand, credit to small and medium size enterprises (SMEs) with a limited credit history, is rationed owing to the lending rate rigidity. The average cost for a loan is 11 percent for large corporations, $16 \frac{1}{2}$ percent for SMEs, and 201/2 percent for households. As a comparison, interest rates on credit extended by microfinance institutions, which are not subject to the ceiling, can reach 30 percent.

16. The deposit structure may also impede long-term credit. As stipulated by current prudential requirements, long-term credit commitments must be financed by long-term deposits. However, because the bulk of deposits in Cameroon is short or medium term in nature (75 percent), private sector credit is dominated by short- and medium-term loans. During 1995-2005, long-term credit averaged less than 1 percent of total credit to the private sector (Figure III.9).

\section{Timely and reliable financial information on potential borrowers is lacking.} Because credit applicants often have no recorded payment history, banks find it difficult to assess borrowers' creditworthiness. For SMEs, this is exacerbated by the poor quality of financial statements presented with loan applications. 


\section{Box III.2. Findings and Recommendations of the CEMAC Regional FSAP}

The 2006 CEMAC regional FSAP assessment found improved financial sector stability but continuing important challenges:

- In relation to the Basel Core Principles (BCP) and the IMF Code of Good Practices on Transparency in Monetary and Financial Policies-Transparency of Banking Supervision, the region generally complies with international best practices, but shortcomings remain in areas of prudential regulation, such as the level and calculation of the solvency ratio and limits to large exposures and the capacity and institutional independence of the regional banking commission.

- A significant number of banks do not meet all prudential rules. With limited implementation capacity, COBAC has shown continued forbearance.

- Stress tests based on individual banks and region-wide data show that the banking sector is particularly vulnerable to credit risks: a relatively large number of banks are undercapitalized and there is a high sectoral concentration of bank loans.

- While a legal framework to criminalize money laundering and combat the financing of terrorism has been adopted, the FSAP assessment found that its implementation is hampered by unclear assignment of responsibilities between regional agencies and national authorities.

\section{The FSAP's main conclusions on financial sector development relate to limited access to} finance, both households and small and medium-sized enterprises (SMEs). The findings are based on discussions with policy-makers and representatives of banks and banking associations and on analysis of detailed banking surveys on lending practices and deposit relations. Key conclusions:

- Banks are reluctant to finance SMEs due to flaws in the legal and judicial framework and poor corporate accounting and governance.

- The imposition on banks of minimum deposit and maximum lending rates curtails access. As a result, banks mainly deal with a small number of large corporate clients.

- Although the microfinance sector has witnessed significant membership growth and emerging linkages with banks in recent years, its outreach is still relatively limited.

- The OHADA (Organization for the Harmonization of African Business Law) accounting framework places an excessive burden on SMEs.

Implementing the recommendations will require actions both at regional and national levels. At the regional level, the recommendations call for

- strengthening the supervisory capacity and institutional independence of COBAC,

- revising the OHADA legislation on debt collection and accounting practices, and

- adjusting administered interest rates to better align with market fundamentals.

At the national level, the recommendations call for

- upgrading the judicial system through, e.g., larger allocations and more training,

- tackling governance issues,

- improving commercial and land registries, and

- adopting a framework for appointing and training insolvency administrators. 
Figure III.9. Cameroon - Credit Structure
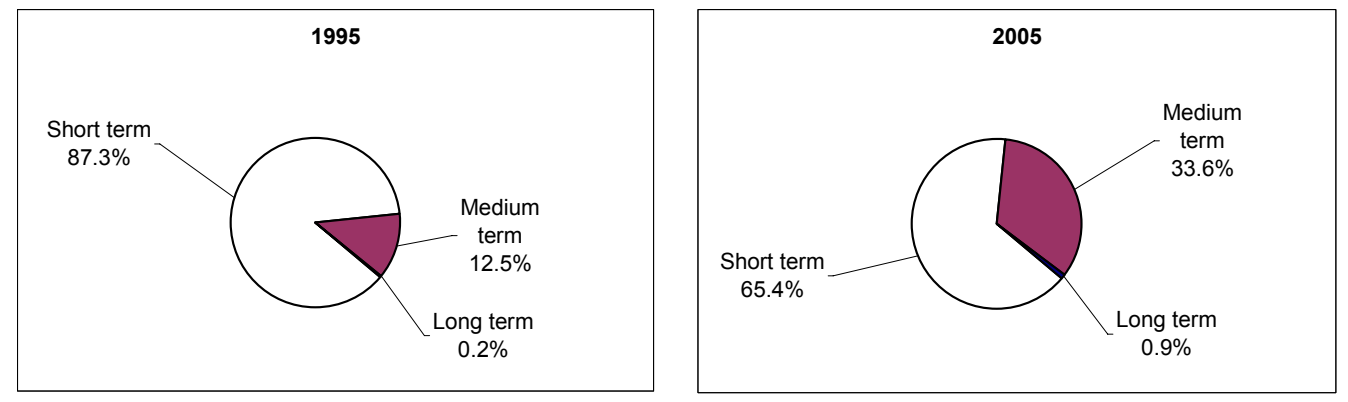

Source: BEAC.

18. Registering property is costly and lengthy, which negatively impacts the use of land and real estate titles in financial transactions (Table III.5). According to the World Bank's "Doing Business" database, it takes almost a month to obtain a copy of the deed for a property in Cameroon, and about three months to register a property title. Registration fees are also high (about 19 percent of the property's value). Moreover, the real-estate registry is in a poor condition and covers only Cameroon's two largest cities.

19. Lack of loan guarantees and inefficiencies in the judicial system constrain credit growth. Banks' requirements on collateral are quite stringent, in view of difficulties in assessing potential borrowers' credit risk. High value collaterals are, however, inaccessible for SMEs, and lower-income households. According to the most recent household survey (2002), nine out ten household requests for investment financing were declined, mostly because of insufficient collateral. Even when borrowers can access collaterals, the weak judicial system limits lending, because lengthy procedures for judgments execution deter acceptance of collaterals.

\section{Fostering financial intermediation would require policy reflections at the national and regional levels in the following areas.}

- Pricing risks. At the regional level, limits on interest rates would need to be reviewed to reflect market conditions. According to the regional FSAP, lifting the ceiling on lending rates would facilitate an optimal risk pricing, give SMEs and households greater access to credit, and allow banks to generate their profits from intermediation rather than fees and commissions. 
Table III. 5 Cameroon and Comparators: Financial Sector Indicators, 2006

\begin{tabular}{|c|c|c|c|c|}
\hline & Cameroon & SSA & CEMAC & OECD \\
\hline \multicolumn{5}{|l|}{ Dealing with licences $^{1}$} \\
\hline Procedures (numbers) & 15.0 & 17.7 & 16.5 & 14.0 \\
\hline Time (days) & 444.0 & 230.2 & 247.8 & 149.5 \\
\hline Cost (percent of income per capita) & 1165.6 & 1024.5 & 709.8 & 72.0 \\
\hline \multicolumn{5}{|l|}{ Registering property $^{2}$} \\
\hline Procedures (numbers) & 5.0 & 7.0 & 5.8 & 4.7 \\
\hline Time (days) & 93.0 & 109.9 & 71.0 & 31.8 \\
\hline Cost (percent of property value) & 18.7 & 11.6 & 15.9 & 4.3 \\
\hline \multicolumn{5}{|l|}{ Getting credit $^{3}$} \\
\hline Legal rights index & 3.0 & 4.2 & 3.2 & 6.3 \\
\hline Credit information index & 2.0 & 1.3 & 1.8 & 5.0 \\
\hline Public registry coverage (percent of adults) & 3.4 & 1.5 & 1.9 & 8.4 \\
\hline Private registry coverage (percent of adults) & 0.0 & 3.8 & 0.0 & 60.8 \\
\hline \multicolumn{5}{|l|}{ Enforcing contracts ${ }^{4}$} \\
\hline Procedures (numbers) & 58.0 & 38.1 & 45.3 & 22.2 \\
\hline Time (days) & 800.0 & 581.1 & 699.3 & 351.2 \\
\hline Cost (percent of debt) & 36.4 & 42.2 & 34.2 & 11.2 \\
\hline \multicolumn{5}{|l|}{ Protecting investors ${ }^{5}$} \\
\hline Investor protection index & 5.3 & 4.7 & 5.1 & 6.0 \\
\hline \multicolumn{5}{|l|}{ Source: World Bank Doing Business Survey. } \\
\hline \multicolumn{5}{|c|}{$\begin{array}{l}{ }^{1} \text { Procedures, time, and costs to build a warehouse, including obtaining necessary licenses } \\
\text { and permits, completing required notifications and inspections, and obtaining utility connections. } \\
{ }^{2} \text { Included are the number of steps, time, and cost involved in registering property. }\end{array}$} \\
\hline \multicolumn{5}{|c|}{$\begin{array}{l}{ }^{3} \text { The Legal Rights Index ranges from } 0-10 \text {, with higher scores indicating that those laws } \\
\text { are better designed to expand access to credit. The Credit Information Index measures } \\
\text { the scope, access, and quality of credit information available through public registries } \\
\text { or private bureaus. It ranges from } 0-6 \text {, with higher values indicating that more credit } \\
\text { information is available from a public registry or private bureau. }\end{array}$} \\
\hline \multicolumn{5}{|c|}{$\begin{array}{l}{ }^{4} \text { This is determined by following the evolution of a payment dispute and tracking the time, } \\
\text { cost, and number of procedures involved from the moment a plaintiff files the lawsuit } \\
\text { until actual payment. }\end{array}$} \\
\hline${ }^{5}$ The index varies between 0 and 10 , with highe & indicating be & investor & ection. & \\
\hline
\end{tabular}

- Financial information. The completion of the ongoing regional project to set up credit bureaus will be an important step. Credit bureaus would collect and disseminate information on borrowers' financial position and payment record, thus eliminating information asymmetry in the market, and enhancing banks' ability to assess and manage risks. Establishing a credit rating system would usefully supplement credit bureaus information. At the national level, the authorities would need to encourage stronger corporate governance and the use of best accounting practices for SMEs. These steps would help improve the quality of SMEs' financial statements. 
- Property registry. To encourage greater use of land and real estate titles as collateral, the authorities would need to take appropriate actions to computerize registries, extend their coverage to other major cities, and reduce registration delays and costs.

- Judicial system. Increased physical and financial resources for courts would support the financial system, particularly by reducing delays in court procedures, execution of collaterals and judgments, dispute settlement, and bankruptcy procedures. In addition, Cameroon would benefit from harmonizing the national business law with that of the Organization for the Harmonization of Business Law in Africa (OHADA), and could take advantage of the OHADA regional training facilities. ${ }^{10}$

\footnotetext{
${ }^{10}$ Cameroon is one of the countries that adhered to OHADA in 1993. The OHADA Uniform Acts cover a wide range of laws and legal arrangements relating to business, and therefore relevant for the financial sector.

Harmonization covers the business and corporate laws, bankruptcy, debt enforcement, accounting and arbitrage.
} 


\section{References}

Abiad, Abdul, and Ashoka Mody, 2005, "Financial Reform. What Shakes It? What Shapes It?" International Monetary Fund, Economic Issues No. 35.

Allen, Donald S., and Ndikumana Léonce Levine, 2000, "Financial Intermediation and Economic Growth in Southern Africa." Journal of African Economies, Vol. 9, No 2, pp. 132-160.

Atindéhou, Roger B., Jean Pierre Gueyie, and Edoh Kossi Amenounve, 2005, "Financial Intermediation and Economic Growth: Evidence from Western Africa," Journal of Applied Financial Economics, No. 15, pp. 777-90.

Claessens Stijn, 2005, “Access to Financial Services: A Review of the Issues and Public Policy Objectives," World Bank Working Paper, No 3589.

Gaytan, Alejandro, and Romain Ranciere, 2001 "The Role of Financial Intermediation in Economic Growth in Sub-Saharan Africa," Canadian Journal of Development Studies, Vol. 13, No. 3, pp. 361-80.

International Monetary Fund, 2006, “Central African Economic and Monetary Community Financial System Stability Assessment.”

------, 2000, “Cameroon, Financial System Stability Assessment."

Kalter, Eliot, 2004, "Chile, Institutions and Policies Underpinning Stability and Growth", IMF, Occasional Paper 231.

Levine, Ross, and Loayza Norman, 2000, "Financial Intermediation and Growth: Causality and Causes." Journal of Monetary Economics, No. 46, pp. 31-77.

Odedokun, M. O., 1998, "Financial Intermediation and Economic Growth in Developing Countries" Journal of Economic Studies, Vol. 25, No 3, pp. 203-24.

Sacerdoti, Emilio, 2005, "Access to Bank Credit in Sub-Saharan Africa: Key Issues and Reform Strategies” IMF Working Paper, No. 05/166.

Spears, Anne, 1992, "The role of Financial Intermediation in Economic Growth in SubSaharan Africa," Canadian Journal of Development Studies, Vol. 13, No 3, pp. 361-80. 
Thornsten Beck, Asli Demirguc-Kunt, and Maria Soledad Martinez Peria, 2005, "Reaching Out: Access to and Use of Banking Services Across Countries" World Bank Working Paper No. 3754. 